\title{
Major Classes of Phytonutriceuticals in Vegetables and Health Benefits: A Review
}

\author{
João Silva Dias*
}

Technical University of Lisbon, Instituto Superior de Agronomia, Tapada da Ajuda, 1349-017 Lisboa, Portugal

\begin{abstract}
Vegetables are essential for well-balanced diets since they supply phytonutriceuticals. About 3 billion people in the world are malnourished due to imbalanced diets. Regular consumption of a vegetable rich diet has undeniable effects on health since they have been strongly associated with improvement of gastrointestinal health, good vision, and reduced risk of heart disease, stroke, chronic diseases such as diabetes, and some forms of cancer. The mechanism by which vegetables decrease risk of disease is complex and largely unknown. Some phytochemicals of vegetables are strong antioxidants and are thought to reduce the risk of chronic disease by protecting against free radical damage, by modifying metabolic activation and detoxification of carcinogens, or even by influencing processes that alter the course of tumor cells. The dietary fiber content and type of different vegetables may also contribute to the overall health benefit. Each vegetable contains a unique combination of phytonutriceuticals. A great diversity of vegetables should be eaten to ensure that individual's diet includes a combination of phytonutriceuticals and to get all the health benefits.
\end{abstract}

Keywords: Antioxidants, dietary fiber, disease control, horticulture, minerals, nutrition, phytochemicals, vitamins.

\section{INTRODUCTION}

Vegetables are essential for well-balanced diets since they play a significant role in human nutrition, especially as sources of phytonutriceuticals: vitamins, minerals, dietary fiber and phytochemicals [1-4]. Some phytochemicals of vegetables are strong antioxidants and are thought to reduce the risk of chronic disease by protecting against free-radical damage, by modifying metabolic activation and detoxification of carcinogens, or even influencing processes that alter the course of tumor cells [2, 3, 5, 6]. Regular consumption of a vegetable rich diet has undeniable positive effects on health since they have been strongly associated with overall good health, improvement of gastrointestinal health and vision, reduced risk for some forms of cancer, heart disease, stroke, diabetes, anaemia, gastric ulcer, rheumatoid arthritis, and other chronic diseases [7-11]. The exact mechanisms by which vegetable consumption reduces human diseases have not yet been fully understood, however the general consensus among physicians and nutritionists is that phytonutriceuticals in vegetables are responsible for mitigating some of these diseases.

"Hidden hunger" or micronutrient deficiency is a pernicious problem around the world that is caused by a lack of vitamins and minerals such as vitamin $A$, iodine and iron in the human diet and affects the health of about 3 billion people worldwide [12, 13]. Underconsumption of vegetables and fruits is among the top

*Address corresponding to this author at the Technical University of Lisbon, Instituto Superior de Agronomia, Tapada da Ajuda, 1349-017 Lisboa, Portugal; Tel: +351.914137940; Fax: +351.213653195; E-mail: mirjsd@gmail.com ten risk factors leading to micronutrient malnutrition and is associated with the prevalence of chronic diseases $[14,15]$. More than $70 \%$ of malnourished children live in Asia. At least half of the preschool children and pregnant women are affected by micronutrient deficiencies in Bangladesh, Cambodia, Nepal and the Philippines [16]. Vegetables contain a range of macroand micronutrients, including pro-vitamin $A$, iron and zinc, which contribute to the prevention of malnutrition disorders. Nutrition is both a quantity and a quality issue, and vegetables in all their many forms ensure an adequate intake of most vitamins and nutrients, dietary fibers, and phytochemicals which can bring a muchneeded measure of balance back to diets, contributing to solving many of these nutrition problems.

A world vegetable survey showed that 402 vegetable crops are cultivated worldwide, representing 69 families and 230 genera $[17,18]$. Leafy vegetables, of which the leaves or young leafy shoots are consumed, are the most often utilized $(53 \%$ of the total), followed by vegetable fruits (15\%), while vegetables with below ground edible organs comprised $17 \%$. Many vegetable crops have more than one part used. Most of the vegetables are market fresh with only a small proportion processed because most vegetables are perishable. Consumption shortly after harvest guarantees optimal vegetable quality.

There are a general belief among nutritionists and health profissionals that the health benefit of vegetables should not be linked to only one compound or one type of vegetable, but rather a balanced diet that includes more than one type of vegetable is likely to provide better protection. This article discusses the 
major classes of phytonutriceuticals in vegetables and their health benefits.

\section{HEALTH PROMOTING PHYTONUTRICEUTICALS IN VEGETABLES}

\subsection{Introduction}

Phytonutriceuticals are all the chemical compounds derived from plants that have health-promoting properties. Most of them are found in relatively small quantities in vegetables. However, when consumed in sufficient quantities, they contribute significantly toward protecting living cells against chronic diseases. The most important phytonutriceuticals in vegetables that have biological activity against chronic diseases are: vitamins, minerals, dietary fiber, organosulfur compounds (glucosinolates and thiosulfides) and flavonoids.

\subsection{Vitamins}

The term vitamin is derived from the words vital and amine, because vitamins are required for life and were originally thought to be amines. Although not all vitamins are amines. They are any of various fatsoluble or water-soluble organic substances essential in minute amounts for normal growth and activity of the body and obtained naturally from plant and animal foods. A healthy body needs vitamins. All vegetables are sources of vitamins and consequently have health benefits. In this section we will highlight and discuss only the vitamins with a high prevalence of inadequated intake in worldwide diets such as vitamins $C, A$, and $E$ and folates.

\subsubsection{Vitamin $C$}

Vitamin $C$ is an essential vitamin to humans that lack the ability to synthesize this vitamin, because they are deficient in the enzyme L-gulonolactone oxidase, an enzime involved in the biosynthesis of vitamin $\mathrm{C}$ via the glucuronic acid pathway. The biological function of vitamin $C$ is based on its ability to donate electrons, which provide intra- and extracellular reducing power for a variety of biochemical reactions. The reducing power of vitamin $C$ is capable of neutralizing most of the physiologically relevant reactive oxygen and nitrogen species in the human body [19]. Several enzymes involved in biosynthesis of collagen, carnitine and neurotransmiters require vitamin $\mathrm{C}$ as a cofactor [20]. Collagen is the most abundant protein in the body, and it forms into fibres which provide strength and stability to all body tissues, including the arteries.
Vitamin C serves also as cofactor for reactions that require reduced iron and/or copper metalloenzymes $[20,21]$. It was also reported as an electron donor for eight enzymes involved in amino acid and hormone synthesis [22]. One of the most important indirect functions of vitamin $\mathrm{C}$ is its ability to regenerate other biologically important antioxidants, such as glutathione and vitamin E, into their reduced states [23-27].

Deficiency of vitamin C in humans has been linked to reduced absorption of amino acids and lower levels of intestinal brush-border membrane proteins and phospholipids [28]. Cardiovascular diseases, several types of cancers, reduced cognitive function and memory, cataracts, risk of asthma and of the common cold, are all associated with vitamin $\mathrm{C}$ deficiency and can be partly prevented by optimal intake of vitamin C. Sing et al. [29] reported a two-fold decrease in coronary heart disease in patients with higher plasma vitamin C compared to the lower group. Several other studies have also confirmed the association between higher plasma vitamin $\mathrm{C}$ concentration and lower risk of death from cardiovascular disease, ranging in benefit from 26 to $60 \%$ [30-32]. Vitamin C consumption has also been shown to reduce uterine cervical [33], colorectal [34, 35], pancreatic [36], lung [37], and gastric [38] cancers. The substantially high cellular levels of vitamin $\mathrm{C}$ provide antioxidant protection in the eye against photosynthetically generated free radicals avoiding cataracts [39] and protects against plasma and low density lipoprotein oxidation [40, 41]. When vitamin $C$ levels are low, the body also manufactures more cholesterol, especially low density lipoprotein. Because of its ability to neutralize free radicals it has been menthioned as having a possible therapeutic use in disorders such as ischemic stroke, Alzheimer's, Parkinson's and Huntington's diseases [42].

Near $90 \%$ of vitamin C in a typical human diet comes from vegetables and fruits (e.g. papaya, pineapple, orange, lemon, kiwifruit). Vitamin $C$ is a water soluble vitamin and is highly sensitive to water, air, and temperature. About $25 \%$ of the vitamin C in vegetables can be lost simply by blanching (boiling or steaming the food for a few minutes). This same degree of loss occurs in the freezing and unthawing of vegetables. Cooking of vegetables for longer periods of time (10-20 minutes) can result in a loss of over onehalf the total vitamin $\mathrm{C}$ content. When vegetables are canned and then reheated, only one-third of the original vitamin $\mathrm{C}$ content may be left. For these reasons, consumption of vitamin C-rich vegetables in their fresh, raw form is the best way to maximize vitamin $C$ intake. 
Vitamin C has significant interactions with several key minerals in the body. Supplemental intake of vitamin C at gram-level doses can interfere with copper metabolism. Conversely, vitamin C can significantly enhance iron uptake and metabolism, even at foodlevel amounts. Vitamin $C$ also has important interactions with other vitamins. Excessive intake of vitamin $A$, for example, is less toxic to the body when vitamin $C$ is readily available. Vitamin $C$ is involved in the regeneration of vitamin $\mathrm{E}$, and these two vitamins appear to work together in their antioxidant effect.

\subsubsection{Vitamin A}

Only animal-based foods and fortified foods provide preformed vitamin A (retinol). Provitamin A carotenoids are supplied by plant-based foods and bioconverted to retinol in the body [43]. Vitamin $A$ is a major public health problem in much of the developing world. It is estimated that in developed countries, almost $70 \%$ of vitamin A comes from animal sources while $30 \%$ is derived from plant-based foods. In contrast, people in developing countries derive about $70 \%$ to $80 \%$ of vitamin A from plant-based foods. Vegetarians and populations with limited access to animal products depend on provitamin A carotenoids. Vitamin A deficiency affects approximately $25 \%$ of the developing world's pre-schoolers. It is associated with blindness, susceptibility to disease and higher mortality rates. It leads to the death of approximately one to three million children each year [44, 45].

The most abundant carotenoids in vegetables are $\alpha$-carotene, $\beta$-carotene, lycopene, lutein, zeaxanthin, and $\beta$-cryptoxanthin [46]. These carotenoids account for more than $90 \%$ of the carotenoids present in the human diet. Carotenoids with molecules containing oxygen, such as lutein, zeaxanthin and $\beta$-cryptoxanthin are known as xanthophylls. The unoxygenated carotenoids such as $\alpha$-carotene, $\beta$-carotene, and lycopene are known as carotenes. The most common carotenes are $\beta$-carotene and lycopene. Lutein is the most abundant xanthophyll. Only three of the carotenoids ( $\alpha$-carotene, $\beta$-carotene, and $\beta$ cryptoxanthin) can be converted into the provitamin $A$ (retinol), while lycopene, lutein, and zeaxanthin have no vitamin A activity. $\beta$-carotene is the carotenoid with the most provitamin A activity, is the more common form, and its also one of the most thoroughly studied. $\beta$-carotene can be found in yellow, orange, and green fruits, roots and leafy vegetables. As a rule of thumb, the greater the intensity of the orange colour of the fruit, root or leafy vegetable, the more $\beta$-carotene it contains. $\beta$-carotene can in fact be transformed to retinol, and this can in turn be transformed into retinal and retionic acid, both of which have different biological functions on many tissues [43]. $\beta$-carotene, as well as its other metabolites, affects important processes such as immunity, reproduction, growth, development and, perhaps its best known function, it holds a vital role in the visual cycle including possible inhibition of macular degeneration and cataracts $[47,48]$. $\beta$-carotene has been characterized as an antioxidant and, like other carotenoids, has been shown to have inhibition mutagenesis activity contributing to decreased risk of some cancers [47]. As an antioxidant, it has been positively linked to diverse ailments related to oxidative stress, such as diabetes [49], obesity [50], low sperm motility [51], hearing loss [52] and others. All the carotenoids can act as antioxidants, although the antioxidant activity of carotenoids differs among the different compounds. Di Mascio et al. [53] reported that the singlet oxygen quenching ability of lycopene is twice that of $\beta$-carotene and ten times that of $\alpha$ tocopherol. The unique nature of the lycopene molecule makes it a very potent antioxidant $[54,55]$. Carotenoids actions include also decreased risk of heart diseases. Gaziano et al. [56] in a study in the USA conducted on 1,273 Massachusetts residents whose ages were greater than 65 years old, found that residents in the upper quartile of high-carotene vegetable intake had $46 \%$ lower risk of death from cardiovascular disease than those in the lowest quartile. In the eye, certain other carotenoids, as the xanthophylls lutein and zeaxanthin, apparently act directly to absorb damaging blue and near-ultraviolet light, in order to protect the macula lutea [57]. Lutein and zeaxanthin reduce the risk of cataract and agerelated macular degeneration $[58,59]$. Vegetables that are rich in these xanthophylls can increase macular pigment density $[57,58]$. Like other carotenoids, xanthophylls are found in highest quantity in the leaves of most green vegetables.

The bioavailability of $\beta$-carotene from vegetables in the human diet is limited. Studies have estimated that $\beta$-carotene bioavailability is 22 to $24 \%$ from broccoli, 19 to $34 \%$ from carrots, and 3 to $6 \%$ from leafy vegetables [60]. Several factors have been shown to influence carotenoids biovailability in humans, the most prominent of which is the food matrix. Studies have shown that combination of fatty foods with carotenoidrich vegetables enhanced carotenoid uptake. Roels et al. [61] reported a one- to fivefold increase in $\beta$ carotene uptake in boys deficient in vitamin $A$, when 
their diet was supplemented with olive oil. Lycopene was found to be more bioavailable from the thermally processed tomato products like tomato paste than from fresh tomato due to heat treatment and the presence of higher oil content in the paste [55, 62]. Lycopene exists in food primarily in the trans sterisomeric configuration; however, cooking and processing help convert translycopene to cis-lycopene, which is more readily absorbed through the intestinal wall into the plasma [63]. Carotenoid availability is also influenced by the nature of the carotenoid. Lutein, which has no vitamin A activity, is five times more readily available in the human body than $\beta$-carotene [64].

\subsubsection{Vitamin $E$}

Vitamin $E$ is a generic term for all tocopherols and their derivatives having biological activity. In nature it is present under eight different forms, four tocopherols $\left(\alpha-, \beta-, \gamma^{-}, \delta\right)$ and four tocotrienols $\left(\alpha-, \beta-, \gamma^{-}, \delta\right)$ [65], of which $\alpha$-tocopherol is the most predominant in nature and most bioactive form [65]. The $\alpha, \beta, \gamma$, and $\delta$ isoforms of tocopherol have relative potencies of $100 \%$, $50 \%, 10 \%$ and $3 \%$, respectively [13]. Since tocopherols are of non-polar nature, their main function lies in their action in the hydrophobic environment of cell and organelle membranes protecting these structures from free radicals and also by stabilizing them [66, 67]. Tocopherols induce a protective effect against oxidative stress linked to metabolic syndrome as well as other sources [68-71]. They are also essential for normal neurological function [72]. As an antioxidant, $\alpha$-tocopherol is able to prevent free-radical mediated tissue damage, and thus to prevent or delay the development of degenerative and inflammatory diseases [73]; in such a role it has been extensively investigated in many species, humans included. Compared with tocopherols, tocotrienols are sparsely studied [74-76]. Some studies have suggested that tocotrienols have specialized roles in protecting neurons from damage [76] and cholesterol reduction [77]. Tocotrienols are also thought to protect against stroke-associated brain damage in vivo [78].

Vitamin E deficiency is believed to be associated with the pathogenesis of cardiovascular disease including low density lipoprotein oxidation, cytokine production, production of lipid mediators, platelet function, and smooth muscle cell proliferation, as well as interaction of the endothelium with immune and inflammatory cells $[66,72,79-82]$. Vitamin $E$ is protective against nearly 80 cellular abnormalities [83], including cardiovascular disease [41, 66, 82, 84, 85], cancer [66, 68, 82], sterility [83], muscular dystrophy $[66,86]$, changes in the central nervous system [87], and anemia development [83]. Since the vitamin is a liposoluble vitamin, it is found primarily in fats. The most important sources are plant-based: oils and margarine, oleaginous fruits, germs of cereals. Fruits and vegetables are the second largest source of vitamin $\mathrm{E}$. They do not contain high levels of vitamin $\mathrm{E}$ (only between 1 and $1.8 \mathrm{mg}$ per $100 \mathrm{~g}$ for the richest sources), but consuming everyday between 100 to 200 $\mathrm{g}$ of vegetables can make them a significant source of Vitamin E. In a normal diet between $12 \%$ and $18 \%$ of our vitamin $E$ intake comes from fruits and vegetables. The current recommended dietary allowance for vitamin $E$ intake from natural foods is about $10-15$ $\mathrm{mg} / \mathrm{day}[88,89]$.

\subsubsection{Folates}

The terms folates (folic acid and tetrahydrofolate) are often used interchangeably for the water-soluble Bcomplex vitamins. Folates are involved as cofactors in carbon transfer reactions in DNA byosynthesis and the methylation cycle [90]. They are an absolute requirement for methionine, purine, and thymidylate synthesis. Tetrahydrofolate is also involved in the synthesis of S-adenosylmethionine, the universal methyl donor in all living cells, and in the control of glycine-to serine conversion [90, 91]. Ames [91] reported that folate deficiency causes chromosome breakage as a result of extensive incorporation of uracil into the human DNA. The human body needs folates to synthesize DNA, repair DNA, and methylate DNA as well as to act as a cofactor in biological reactions involving folates [92]. It is especially important in aiding rapid cell division and growth such as in infancy and pregnancy. Children and adults require folate to produce healthy red blood cells and prevent anaemia. Folate deficiency, which is regarded as a global health problem mainly in developing countries, can result in many health problems. The most notable ones are neural tube defects in developing embryos, and abnormal fetal growth and risks during pregnancy. Neural tube defects produce malformations of the spine, skull, and brain including spina bifida and anencephaly. Epidemiological studies have shown that folate deficiency contributes to an accumulation of homocysteine leading to neural tube defects such as spina bifida in fetuses [93]. The risk of neural tube defects is significantly reduced when supplemental folic acid is consumed in addition to a healthy vegetable diet prior to and during the first month following conception $[94,95]$. Folate deficiency during pregnancy may also 
increase the risk of preterm delivery, infant low birth weight and fetal growth retardation, as well as increasing homocysteine level in the blood, which may lead to spontaneous abortion and pregnancy complications, such as placental abruption and preeclampsia [96]. Women who could become pregnant are advised to eat foods fortified with folic acid or take supplements in addition to eating folate-rich vegetable foods to reduce the risk of serious birth defects [97-99].

Folate deficiency is also linked to colon cancer risk $[100,101]$, neurotoxicity [102], and heart attacks [103106]. Most research studies associate high dietary folate intake with a reduced risk of prostate cancer $[107,108]$. However folate has shown to play a dual role in cancer development: low folate intake protects against early carcinogenesis, and high folate intake promotes advanced carcinogenesis [109]. Therefore, public health recommendations should be careful not to encourage too much folate intake mainly as folic acid supplements. Vegetables such as broccoli, Brussels sprouts, and potato were reported to contribute between 35 to $40 \%$ of the total intake of folate in the human diet [90].

\subsection{Minerals}

\subsubsection{Introduction}

Minerals are inorganic substances that are originally found in rocks and soil. The vegetables we eat absorbed plenty of minerals as they were growing. When we eat those vegetables, we absorb the minerals as we digest food. All vegetables are sources of minerals and consequently have health benefits. A healthy body needs plenty of minerals. Minerals can be divided into two groups. There are some that we need only in tiny quantities (trace) and others that we need much more of (major). Major minerals, macronutrients, with a high prevalence of inadequate intake in worldwide diets include calcium, magnesium, and potassium. Trace minerals, micronutrients, identified as nutrients with great health implications and benefits, usually with a high prevalence of inadequate intake, include iron, zinc and selenium.

\subsubsection{Calcium}

Calcium is an important component of a healthy diet and a mineral necessary for life. It is essential for strong bones and teeth. Calcium plays an important role in building stronger, denser bones early in life and keeping bones strong and healthy later in life [110]. Approximately $99 \%$ of the body's calcium is stored in the bones and teeth. The rest of the calcium in the body has other important uses, such as some exocytosis, especially neurotransmitter release, and muscle contraction. In the electrical conduction system of the heart, calcium replaces sodium as the mineral that depolarizes the cell, proliferating the action potential. Calcium eases insomnia and helps regulate the passage of nutrients through cell walls. If we don't get enough calcium from the food we eat, our bodies automatically take the calcium needed from our bones. If our bodies continue to tear down more bone than they replace over a period of years in order to get sufficient calcium, our bones will become weak and break easily. Calcium deficiency may result in muscle spasms and cramps in the short term, and osteoporosis. Without calcium, our muscles wouldn't contract correctly, our blood wouldn't clot and our nerves wouldn't carry messages. While a lifelong deficit can affect bone and tooth formation, over-retention can cause hypercalcemia, impaired kidney function and decreased absorption of other minerals [111]. High calcium intakes or high calcium absorption were previously thought to contribute to the development of kidney stones. However, a high calcium intake has been associated with a lower risk for kidney stones in more recent research $[112,113]$. Vitamin $D$ is needed to absorb calcium. Absorption of calcium may be poor when consumed with foods rich in phytic acid (e.g. unleavened bread, raw beans, fibre rich foods, etc.) or oxalic acid (e.g. New Zealand spinach, spinach, Swiss chard, beet greens) [114]. Phytic acid (inositol hexaphosphate, Ins $P_{6}$ ) is the storage form of phosphorus. It contains six phosphate groups, thereby it can act as metal chelator of important minerals such as calcium, magnesium, iron, zinc and can contribute to mineral deficiencies in people. Salt of phytic acid with minerals or protein complexes are known as phytates. Compared to calcium absorption from milk, calcium from prepared dried beans and spinach is reduced by about $50 \%$ and $90 \%$, respectively [114, 115]. Recent studies demonstrate that this "antinutrient" effect of phytic acid is only manifested when large quantities of phytic acid are consumed in combination with an micronutrient-poor diet [116].

Though most people think immediately of dairy products when it comes to calcium, there are plenty of vegetable good sources too (e.g. kales, tronchuda cabbages, pak-choy, kailan, rutabaga, turnip, chard, rhubarb, okra, onions, amaranth, Brussels sprouts, squash, celery, parsnip, beans, etc.). For example, Galega kale contains a high content of protein, fiber, 
calcium, and sulfur when compared to broccoli, the reference within Brassica vegetables. For many years Galega kale, based on the levels of protein and calcium, was assumed to be a substitute for milk in the poorest rural areas of Portugal where the peasants could not afford to buy milk or even raise cows [117, 118].

\subsubsection{Magnesium}

Magnesium is the eleventh most abundant element by mass in the human body. Its ions are essential to all living cells, where they play a major role in manipulating important biological polyphosphate compounds like ATP, DNA, and RNA [119]. Hundreds of enzymes thus require magnesium ions to function. ATP exists in cells normally as a chelate of ATP and a magnesium ion. Magnesium helps our body to release energy from food. Magnesium is needed for bone, protein, making new cells, activating $B$ vitamins, relaxing nerves and muscles, clotting blood, and in energy production [120]. Insulin secretion and function also requires magnesium [121, 122]. Magnesium also assists in the absorption of calcium, vitamin $C$ and potassium. Deficiency may result in fatigue, nervousness, insomnia, heart problems, high blood pressure, osteoporosis, muscle weakness and cramps [123-125]. Low levels of magnesium in the body has been associated with the development of a number of human illnesses such as asthma, diabetes, and osteoporosis [126-128]. All the green leafy vegetables are good sources of magnesium as they contain chlorophyll.

\subsubsection{Potassium}

Potassium is the eighth most common element by mass $(0.2 \%)$ in the human body, so that a $60 \mathrm{~kg}$ adult contains a total of about 120 grams of potassium [129]. Potassium ions are necessary for the function of all living cells. It is essential for the body's growth and maintenance. Potassium cations are important in neuron (brain and nerve) function, and in influencing osmotic balance between cells and the interstitial fluid, with their distribution mediated in all animals by the socalled $\mathrm{Na}+/ \mathrm{K}+-$-ATPase pump $[119,130]$. Potassium ion diffusion is a key mechanism in nerve transmission and is important in preventing muscle contraction. Its depletion in humans, results in various cardiac dysfunctions. Potassium plays an essential role in proper heart function [131]. A shortage of potassium in body fluids may cause a potentially fatal condition known as hypokalemia, typically resulting from vomiting, diarrhea, and/or increased diuresis [132].
Deficiency may cause muscular cramps, twitching and muscle weakness, cardiac arrhythmia, insomnia, kidney failure and decreased lung reflex response and in severe cases respiratory paralysis. Epidemiological studies and studies in animals subject to hypertension indicate that diets high in potassium can reduce the risk of hypertension and possibly stroke by a mechanism independent of blood pressure [131]. Potassium is found in especially high concentrations within plant cells, and in a mixed diet, it is mostly concentrated in fruits and vegetables [19].

\subsubsection{Iron}

Iron plays an important role in human health, forming complexes with molecular oxygen in hemoglobin and myoglobin [119]. These two compounds are common oxygen transport proteins in vertebrates. Iron is also the metal used at the active site of many important redox enzymes dealing with cellular respiration and oxidation and reduction in plants and animals [119]. Too little iron in human diet can lead to anaemia. Iron is found in food in two forms, heme and non-heme iron. Heme iron, which makes up $40 \%$ of the iron in meat, poultry, and fish, is well absorbed (has higher bioavailability). Non-heme iron, $60 \%$ of the iron in animal tissue and all the iron in plants (fruits, vegetables, grains, nuts) is less well absorbed. Vegan diets only contain non-heme iron. Because of this, iron recommendations are higher for vegetarians (including vegans who consume only plant foods) than for non-vegetarians. Red meat is the most obvious source of iron, but there are also good vegetable sources. Dried beans, lentils, peas, as well as all the other legumes, and dark green leafy vegetables are especially good sources of iron, even better on a per calorie basis than meat.

Iron deficiency is the most prevalent form of malnutrition worldwide, affecting an estimated two billion people. Eradicating iron deficiency can improve national productivity levels by as much as $20 \%$ [44, 133]. Most at risk of iron deficiency are infants, adolescent girls and pregnant women. Pregnant women are at special risk of low iron levels and are often advised to supplement their iron intake [134]. Iron deficiency in infants can result in impaired learning ability and behavioral problems [45]. It can also affect the immune system and cause weakness and fatigue. Vitamin C promotes the absorption of non-heme iron. It is necessary to eat foods rich in vitamin $C$ at the same time we eat the food containing iron. Foods rich in phytic acid limit the absorption of non-heme iron [114]. 
The recommended dietary allowance for iron varies considerably based on age, gender, and source of dietary iron [135]. Women and teenage girls need at least $15 \mathrm{mg}$ a day, whereas men can get by on $10 \mathrm{mg}$. It is important that children get about 10 to $12 \mathrm{mg}$ of iron per day, preferably from their diets $[135,136]$. Vegetarians need to get twice as much dietary iron as meat eaters. Surveys of vegans $[137,138]$ have found that iron deficiency anaemia is no more common among vegetarians than among the general population although vegans tend to have lower iron stores [138]. The reason for the satisfactory iron status of many vegans may be that commonly eaten foods are high in iron, than animal-derived foods. For example, we would have to eat more than 1,700 calories of sirloin steak to get the same amount of iron as found in 100 calories of spinach. Another reason for the satisfactory iron status of vegans is that vegetarian diets are higher in vitamin C. Vitamin C acts to markedly increase absorption of non-heme iron. Adding a vitamin $C$ source to a meal increases non-heme iron absorption up to six fold, which makes the absorption of non-heme iron as good as or better than that of heme iron [139]. Fortunately, many vegetables, such as broccoli and pak-choy, which are high in iron, are also high in vitamin $\mathrm{C}$ so that the iron in these foods is very well absorbed. Commonly vegan eaten combinations, such as beans or lentils and tomato sauce or stir-fried tofu and broccoli or pak-choy, also result in generous levels of iron absorption. Both calcium and tannins reduce iron absorption [140].

\subsubsection{Zinc}

Zinc is a mineral of exceptional biologic and public health importance [141]. Zinc is found in nearly 100 specific enzymes, serves as structural ions in transcription factors and is stored and transferred in metallothioneins [119]. It is the second most abundant transition metal in organisms after iron, and it is the only metal that appears in all enzyme classes [142]. In proteins, zinc ions are often coordinated to the amino acid side chains of aspartic acid, glutamic acid, cysteine and histidine [119, 143]. Zinc deficiency affects about 2 billion people in the developing world and is associated with many diseases [144]. In children, it causes relax skin, growth retardation, delayed sexual maturation, infection susceptibility, and diarrhea, contributing to the death of about 800,000 children worldwide per year [141]. The World Health Organization advocates zinc supplementation for severe malnutrition and diarrhea [145]. Zinc supplements help prevent disease and reduce mortality, especially among children with low birth weight or stunted growth [145]. However, zinc supplements should not be administered alone, since many in the developing world have several deficiencies, and zinc interacts with other micronutrients [146].

The concentration of zinc in vegetables and plants varies based on levels of the element in soil. Zinc deficiency is crop plants' most common micronutrient deficiency. It is particularly common in high-pH soils. Plants that grow in soils that are zinc-deficient are more susceptible to disease. When there is adequate zinc in the soil, the plant sources that contain the most zinc are wheat (germ and bran) and various seeds (sesame, poppy, alfalfa, celery, mustard) [147]. Zinc is also found in vegetables such as beans, peas, pumpkin seeds, sea vegetables, and in nuts, almonds, whole grains, sunflower seeds, soy foods and blackcurrant [89]. However, phytic acid/phytates in many wholegrains and dietary fiber in many foods may interfere with zinc absorption, and marginal zinc intake has poorly understood effects [114].Vegetarians need about $50 \%$ more zinc in their diets than meat-eaters. Despite some concerns, Western vegetarians and vegans have not been found to suffer from overt zinc deficiencies any more than meat-eaters [148].

\subsubsection{Selenium}

Selenium is an essential trace mineral in humans. Its importance is underlined by the fact that it is the only trace mineral to be specified in the genetic code as selenocysteine. Selenium is a key component of several functional selenoproteins (e.g., glutathione peroxidases, thioredoxin reductases, iodothyronine deiodinases and selenoprotein $\mathrm{P}$ ) that protect tissues and membranes from oxidative stress and controls the cell redox status [149]. The antioxidant properties of selenoproteins help prevent cellular damage from free radicals. Free radicals are natural by-products of oxygen metabolism that may contribute to the development of chronic diseases such as cancer and heart disease. Other selenoproteins help regulate thyroid function and play a role in the immune system [149]. Selenium is found in human hairs and nails, and in the blood. Most selenium in animal and plant tissue is present in the unusual amino acids selenocysteine and selenomethionine. Animal tissues, however, are not capable of synthesizing selenomethionine, instead they obtain it from plant tissue. Plant-based selenomethionine accounts for nearly half of the daily requirement of selenium in humans, while the balance 
is obtained from water (as selenate and selenite), milk, fish, and animal based products [150]. Selenocysteine and selenomethionine are readily absorbed by human tissue [151].

Several studies have suggested an increase risk of cancer with low selenium diet [152-157]. Helzlsouer et al. [158] indicated that women in the higher group of serum-selenium levels content were four times likely to develop ovarian cancer than women in the lower group. In another study, Yoshizawa et al. [159] reported a $33 \%$ reduction in prostate cancer in men receiving a $200 \mu \mathrm{g}$ selenium per day supplement compared to the control. Clark et al. [160] conducted a study to test the effect of selenium supplementation on the recurrence of skin cancers on selenium-deficient men. They found that men receiving $200 \mu \mathrm{g}$ selenium per day were $50 \%$ less likely to develop or die from carcinoma of skin than those receiving a placebo. This study did not demonstrate a reduced rate of recurrence of skin cancers, but did show a reduced occurrence of total cancers, particularly for lung, colorectal and prostate cancers. Dietary selenium prevents chemically induced carcinogenesis in many rodent studies. It has been proposed that selenium may help prevent cancer by acting as an antioxidant or by enhancing immune activity. Generally, selenium functions as an antioxidant that works in conjunction with vitamin $\mathrm{E}$. Tsavachidou et al. [161] report that vitamin E (400 IU) and selenium $(200 \mu \mathrm{g})$ supplements affect gene expression and can act as a tumor suppressor in prostate cancer.

Selenium deficiency in human and animal models has also been linked to cardiovascular diseases [162] and rheumatic arthritis [163]. Keshan disease, a disease of the heart, and Kashin-Beck disease, a disease of the cartilage, have been also linked to selenium deficiency that occurs almost exclusively in children and adolescents $[164,165]$. These two diseases occur mostly in Southeast Asia in areas with severe selenium deficiency. Although Moreno-Reyes et al. [166] stated that the effect of selenium deficiency on health remains uncertain, particularly in relation to Kashin-Beck disease. Selenium may inhibit Hashimotos's disease, in which the body's own thyroid cells are attacked as alien. A reduction of $21 \%$ on thyroid peroxidase antibodies was reported with the dietary intake of $0.2 \mathrm{mg}$ of selenium [167]. Evidence from in vivo and in vitro studies suggests that selenium could enhance insulin sensitivity by mediating insulinlike actions [168-170]. Akbaraly et al. [171] in recent studies indicated that selenium may help inhibit the development of type 2 diabetes (diabetes at an advanced age) in men. The mechanism by which selenium may protect against dysglycemia in this study is unclear but may involve the selenoenzymes.

\subsection{Dietary Fiber}

Dietary fiber is a heterogeneous mixture of polysaccharide carbohydrates, such as cellulose, hemicellulose, $\beta$-glucans, pectins, mucilages and gums, plus noncarbohydrates, such as lignin, which are indigestible in the small intestine [172]. Dietary fiber is classified into water-soluble and water-insoluble fiber. Water-insoluble fiber is mainly cell wall components, such as cellulose, lignin, and hemicellulose found in the vegetables. Health benefits of insoluble fiber include shortening of the bowel transit time and bulkier and softer feces. Non-cellulosic polysaccharides, such as pectin, gums, and mucilages, are components of soluble fiber. Soluble fiber delays gastric emptying, slows glucose absorption, and lowers serum cholesterol levels, and is completely or partially fermentable in the large intestine [173]. Fermentation produces short-chain fatty acids that have many health benefits related to blood glucose levels, cholesterol synthesis, immune function, and colon health.

Dietary fiber is a major constituent of vegetables. Anderson and Bridges [174] evaluated the dietary fiber content of several food groups. They found that vegetables contain about $32 \%$ dietary fiber, based on dry weight, which they estimated to be equivalent to the amount found in many cereal products. Although vegetables possess a higher water-soluble/insoluble fiber ratio than cereals, which is considered as an indicator of good nutritional quality [175]. Pectin constitutes nearly $30 \%$ of the dietary content in vegetables [176]. Physiological and physicochemical effects of dietary fibers depend on the relative amount of individual non-digestible components [175].

The importance of dietary fiber in nutrition and its health benefits are widely recognized. Numerous clinical and epidemiological studies have addressed the role of dietary fibre in intestinal health, prevention of cardiovascular disease, some types of cancer, peptic ulcer, obesity, and diabetes [175]. Dietary fiber has many functions in diet, one of which may be to aid in energy intake control and reduced risk for development of obesity. The role of dietary fiber in energy intake regulation and obesity development is related to its unique physical and chemical properties that aid in early signals of satiation and enhanced or prolonged signals of satiety [177]. Early signals of satiation may 
be induced through cephalic- and gastric-phase responses related to the bulking effects of dietary fiber on energy density and palatability, whereas the viscosity-producing effects of certain fibers may enhance satiety through intestinal-phase events related to modified gastrointestinal function and subsequent delay in fat absorption. There is a strong relationship between dietary fiber intake and lower risk of type 2 diabetes. Several mechanisms have been proposed for this inhibition, including improved insulin sensitivity and/or decreased insulin requirement [178]. The mechanisms involved in cardiovascular disease are: lower blood pressure [179], and decrease total serum cholesterol and low-density lipoprotein concentrations [173]. Other effects of dietary fiber include increased stool-bulking which dilutes chemical carcinogens, and increased production of the anticarcinogen butyric acid through fermentation of dietary fiber by the colon microflora. Le Marchand et al. [180] conducted a study among different ethnic groups and genders in Hawaii to evaluate the role of dietary fiber on the risk of colorectal cancer. Their results suggested a strong inverse association between vegetable dietary fiber (soluble and insoluble) and colorectal cancer. In spite of many years of research and nutrition education about potential benefits of dietary fiber to help prevent diseases such as cancer, heart disease, and diabetes, the consumption of complex carbohydrates and dietary fiber worldwide has decreased [181]. The recommended daily intake of dietary fibre is $25-35$ g/person [175].

Dietary fiber and other phytonutriceuticals are generally addressed separately as groups of food constituents in nutritional studies. However, dietary fibre of vegetables transports a significant amount of polyphenols and carotenoids linked to the fibre matrix through the human gut $[182,183]$. Therefore, associated phytochemicals can make a significant contribution to the health benefits attributed to the dietary fibre of vegetables. Moreover, phytochemicals may be considered dietary fibre constituents in view of the similarity of their properties in terms of resistance to digestive enzymes and colonic fermentability [182, 183]. In the Spanish diet, considered as Mediterranean pattern diet, fruit and vegetables provide a daily intake of $700-1,000 \mathrm{mg}$ of polyphenols/person/diet, a major fraction of this (600 mg/person/day) is associated with dietary fiber [183]. These issues constitute an important qualitative difference in relation to other dietary patterns.

\subsection{Organosulfur Compounds}

The two major organosulfur compounds in vegetables that have been found to have biological activity against important human diseases are glucosinolates and thiosulfites.

\subsubsection{Glucosinolates}

Glucosinolates or $\beta$-D-thioglucosides, are sulfur containing secondary metabolites. Briefly, the glucosinolate molecule comprises a skeletal $\beta$ thioglucose moiety, a sulfonated oxime moiety (glucone), and an aglucone R-group that defines the structure of each glucosinolate. More than 100 glucosinolates have been identified from 16 plant families of dicotyledonous plants [184, 185]. Of the nearly 120 glucosinolates that have been identified in plants thus far, about 20 have been detected in crucifers, and of those, only three or four are present in significant amounts [185]. Based on their R-group structure, glucosinolates have been classified into aliphatic, aromatic, and indolyl. The mostly present glucosinolates in crucifers are the aliphatic, followed by the indoles, and then the aromatic. The aliphatic glucosinolates include glucoraphanin, glucoerucin, progoitrin, epi-progoitrin, sinigrin, napoleiferin, gluconapin, and glucoalysin; the indoles include glucobrassicin and 4-hydroxyglucobrassicin, 4methoxyglucobrassicin, and glucobrassicin; and the aromatics include gluconasturtiin and sinalbin.

Many compounds occurring naturally in the human diet moderate the biotransformation of several carcinogens, resulting in reduced tumour incidence [186]. Glucosinolates and their hydrolytic products modulate the activity of xenobiotic metabolising phase I and II enzymes. Phase I enzymes responsible for bioactivation of carcinogens generally increase the reactivity of lipophilic compounds. On the other hand, phase II detoxification enzymes increase the water solubility and facilitate removal of these metabolites from the body. For the protection of cells against DNA damage by carcinogens and reactive oxygen species, inhibition of phase I and induction of phase II enzymes are required. The genes for the phase II enzyme contain a specific sequence of DNA called antioxidant response element. Activities of phase II enzyme have been reported to be enhanced by glucosinolates and their hydrolytic products [187].

Several studies have suggested that intact glucosinolates have no biological activity against cancer, however their breakdown products have been 
shown to stimulate mixed-function oxidases involved in detoxification of carcinogens, reducing the risk of certain cancers in humans [185, 188, 189]. In crucifers, when plant tissues are cut, chewed or otherwise damaged, glucosinolates are hydrolysed by the enzymatic action of myrosinase [thioglucoside glucohydrolase, EC 3.2.3.1 [190] releasing biologically active products including isothiocyanates, thiocyanates, indoles and nitriles [191]. However, when these tissues are cooked or longer steamed the enzyme myrosinase is completely inactivated. It has been suggested that myrosinase activity produced by the stomach microflora is capable of breaking down glucosinolates into active products [192]. While intact glucosinolates have no biological activity against chronic diseases, certain myrosinase catalysed-breakdown products of glucosinolates have been shown to reduce chemically induced carcinogens. However, not all glucosinolate breakdown products have anticancer activity [193]. The glucosinolates glucoraphanin, glucoiberin, glucobrassicin and gluconasturtiin are involved in the anticarcinogenic activity and glucoraphanin is known to bolster the defences of cells against carcinogens through an up-regulation of enzymes of carcinogen defence (phase II enzymes).

Isothiocyanates are an important group of breakdown products of glucosinolates and appear to act at a number of points in the tumour development by blocking the metabolism of carcinogenic compounds through biotransformation. They generally enhanced the activity of phase II enzymes and inhibited phase I enzymes [194, 195], thus reducing the carcinogenic activity and enhance the detoxification and clearance of carcinogens. Further, they serve as suppressors during the promotion phase of neo-plastic process. Induction of apoptosis and action of signal transduction pathways within the cell activities of glucosinolates has also been reported [196]. Watercress and broccoli are reported to be rich sources of phenethyl isothiocyanate which may block the cytochrome P450 mediated metabolic activation of the common nitrosoamine to its potent carcinogenic forms [197]. Extracts of watercress and broccoli suppressed metalloproteinase-9, an enzyme closely associated with invasive potential of breast cancer [194]. It also suppressed production of proinflammatory compounds such as nitric oxide (NO) and prostaglandins [198]. Phenethyl isothiocyanate also inhibited induction of lung and oesophagus cancer in both rat and mouse tumours [199-201].

Sulpharophane

(4-methylulfinylbutyl isothiocyanate), and indole-3-carbinol are the two most widely studied glucosinolate breakdown products exhibiting anticarcinogenic properties [202-204]. Sulforaphane, enzymatic hydrolysis degradation product of glucosinolate glucoraphanin [205], activates gene expression, thereby, helping to clear carcinogenic substances from the body. Sulforaphane also increased levels of mammalian phase II enzymes through antioxidant response element mediated transcriptional activation [202, 203, 206-208]. Sulforaphane supported a healthy immune system by significantly enhancing the production of chemicals involved in immune response [209]. In a study in which animals were genetically bred to develop intestinal polyps, a condition that led to tumour formation, the group of animals that were fed with sulphoraphane had higher rates of apoptosis (cell suicide) and smaller tumour growing more slowly than animals not receiving sulphoraphane [210]. Indole-3-carbinol is produced from indole-3-glucosinolates like glucobrassicin through hydrolysis [211]. Under acidic conditions, indole-3carbinol and elemental sulphur are formed. Anti carcinogenic, antioxidant and antiatherogenic activities of indole-3-carbinol have been reported [211]. Further, indole-3-carbinol modulates the activities of both phase I and II enzymes. It suppressed cancer growth and induced programmed cell deaths in tumours of breast, prostate, leukaemia, cervix and colon because of its ability to favourably influence the human body's balance of estrogens [212-215]. Indole-3-carbinol also inhibited cancer cell growth by interfering the production of proteins involved in abnormal cellular reproduction and by promoting the production of tumour suppressor proteins $[215,216]$. Indole-3carbinol has also been reported to prevent cancer by interfering with angiogenesis, process of formation of new blood vessels that tumour require for their survival and spread [217].

Glucosinolates levels are affected by methods of food preparation. Various studies have shown large effects of cooking Brassica vegetables mostly resulting in substantial losses by leaching of glucosinolates into the cooking water since glucosinolates are watersoluble [191, 218-220]. Goodrich et al. [218] and Rosa and Heaney [219] reported 40 to $80 \%$ leaching of glucosinolates from cabbage leaves, Brussels sprouts, and broccoli heads into the cooking water. Leaching of glucosinolates was significantly lower for Brussels sprouts than broccoli or cabbage, possibly due to the compactness of the sprout. Vallejo et al. [220] in broccoli showed large differences in glucosinolate levels among four cooking processes. Conventional 
and microwave cooking caused substantial losses of total glucosinolates while steaming had minimal effects on glucosinolates [191, 220]. On the other hand Verkerk and Dekker [221] demonstrated high retention of glucosinolates after microwave cooking of red cabbage, even up to levels exceeding the total glucosinolate content of the untreated vegetables. The authors ascribed these higher levels to increased extractability of the glucosinolates [221]. Verkerk et al. [191] also observed that steaming resulted in high retention of total aliphatic and indolyl glucosinolates in cooked broccoli, and that only after extensive steaming of broccoli (30 min) substantial losses of total indolyl glucosinolates of $55 \%$ and total aliphatic glucosinolates of $8.5 \%$ were observed. These authors also observed that steaming broccoli for more than six min results in complete inactivation of the hydrolic enzyme myronase. However, steaming of broccoli for less than six min may result in a high intake of glucosinolates, in the presence of a residual active myronase, allowing the release of health-protective breakdown products of glucosinolates after consumption. Therefore, steaming for less than six min produces broccoli with high levels of glucosinolates and yet, residual active myronase enabling a more efficient conversion of glucosinolates during mastication into the health-protective isothiocyanates.

\subsubsection{Thiosulfides}

Thiosulfides are organosulfur compounds (OSCs) found in alliums [222]. The composition of OSCs differs depending on the Allium specie [223], plant cultivation and processing methods [224]. Some thiosulfides are absent in the bulbs and require mechanical exposure like cutting or chewing to be formed. According to Verma and Verma [224] whole garlic bulbs contain 16 OSCs versus 23 OSCs after crushing. In another study, Kalra et al. [225] reported 33 OSCs in fresh garlic. Sallyl-cysteine sulfoxide (alliin), S-methyl-cystein sulfoxide (methiin), and y-glutamylcysteine are reported as the major thiosulfides in the cytoplasm of intact tissues of alliums [224, 226]. Other minor thiosulfides include S-propenil-cystein sulfoxide (isoalliin) and Sethyl-cystein, commonly known as ethiin [224, 227]. None of the thiosulfides found in alliums have been detected in other vegetables, except methiin, which was detected in cabbage leaves and some Brassicaceae [228]. Several surveys of the thiosulfide content of alliums have been conducted in the last years [224, 225, 229-232]. The pathways for biosynthesis of thiosulfides in alliums have not been very clearly defined because of their diversity and instability. For example, alliin, the most abundant thiosulfide in intact garlic, is highly unstable. When garlic tissue is cut, chewed, or dehydrated, cytosolic alliin is rapidly lysed by the vacuolar enzyme alliinase or alliin lyase (E alliin alkyl-sulphenate-lyase, C 4.4.1.4) into a highly unstable diallyl thiosulfinate transient intermediate called allicin [233, 234]. Allicin then converts into several lipid-soluble alkyl alkanethiosulfinates, including allyl sulfide, diallyl disulfide, diallyl trisulfide, allylmethyl disulfide, 2- and 3-vinyl dithiins, thioacroleines, and ajoene [235-238]. These lipid soluble compounds form the odiferous and aromatic characteristic of garlic. The type and amount of the thiosulfides in alliums varied considerably, depending on the level of alliinase activity and the nature of the substrate. The thiosulfides detected in onions are S-propenyl-cystein sulfoxide, S-methilcysteine sulfoxide, and S-propyl-cystein sulfoxide [226, $228,239]$. Variations in the ratios of these volatile sulfur compounds are responsible for the difference in flavors and odors between Allium species [233, 240]. More than 80 volatile compounds of this class have been identified fresh or cooked vegetable alliums [241]. They are also major contributors to the bitter taste of some onions [240].

Consumption of Allium vegetables has been found to retard growth of several types of cancers. It has generally been accepted that the in vivo and in vitro anti-proliferative effect of Allium vegetables results from the breakdown of alliin into organosulfur compounds [242-246]. Knowles and Milner [247] listed seven allyl sulfides (alicin, diallyl sulfide, diallyl disulfide, diallyl trisulfide, ajoene, S-allyl cysteine, and Sallylmercaptocysteine) that have been reported to inhibit human tumor growth including prostate, colon, skin, breast, lung, lymphoma, erythroleukemia, and lymphocyte tumors. Examination of the mechanism of cancer prevention by organosulfur compounds indicates that they function as blocking agents. Blocking agents act during the initiation stage of carcinogenesis by either inhibiting the activation of procarcinogens, trapping reactive species, or by enhancing phase II enzymes. In addition to enhancing the activity of phase II detoxification enzymes, ally sulfides also inhibit phase I enzymes, such as cytochrome P450 2E1, which have been shown to activate chemical carcinogens, and promote apoptosis [248-250]. However, there are significant differences in the ability of allyl sulfides to inhibit tumor cell growth. For example, Knowles and Milner [247] reported that diallyl disulfides were twice as effective as 
S-allylmercaptocysteine in inhibiting human colon tumor growth. Diallyl trisulfide was also reported to be at least 2.5 times more effective in controlling lung tumor growth than diallyl disulfide [251, 252]. Cancers of the digestive tract and prostate appear to be the most sensitive ones to the chemopreventive effects of Allium vegetables intake which may reflect a problem of thiosulfides stability. Tissues/organs, which are in inner connection with the digestive/urinary systems, are obviously exposed to higher concentrations of biologically active products deriving from the degradation/catabolism of any ingested food. This encourages efforts aimed to increasing the stability of these compounds (without increasing also their toxicity). The conjugation of molecules specifically recognizing and binding to cancer cells together with the enzyme allinase could generate high concentrations of alliin right at the tumor site and may represent an interesting attempt to overcome this limiting factor [253].

Another important health benefit of allyl sulfides is their ability to protect humans against cardiovascular diseases. Cardiovascular diseases are controlled by a multitude of factors including high serum cholesterol, high levels of low-density lipoproteins, high blood pressure, and platelet aggregation. Aggregation of platelets in the blood increases the risk of thrombosis and, as a consequence the risk of cardiac attack. Liu and Yeh [254] examined the effect of eleven water and lipide soluble organosulfur compounds from garlic on the incorporation of $\left[2-{ }^{14} \mathrm{C}\right]$-acetate into cholesterol in rat hepatocyte cells. They found that seven of the allyl sulfides tested inhibited cholesterol syntesis by as much as $55 \%$ and that higher concentrations of diallyl disulfide, diallyl trisulfide, and dipropyl disulfide resulted in complete inhibition of cholesterol syntesis. Ide and Lau [255] reported that S-allylcyteine and other thiosulfides prevent low-density lipoprotein oxidation in vascular endothelial cells. Organosulfur compounds from garlic and onion, have been suggested to reduce platelet aggregation, thereby lowering the risk of heart attack and/or stroke [256, 257]. Lawson et al. [258] demonstrated that diallyl disulfide, diallyl trisulfide, and ajoene, from garlic, have in vitro antiplatelet activity. Similarly, Morimitsu et al. [259] and Ali et al. [260] reported that organosulfur compounds found in onions, mostly cepaenes, also have antiplatelet activity. A preliminary study conducted this time on humans showed that the consumption of the equivalent of three onions in a soup was sufficient to significantly reduce the blood platelet aggregation [261]. This activity appears to be less important after cooking [262] and more important in pungent onions [263]. It is attributed to quercetin and alkyl-propenyl cysteine sulphoxide molecules, but the exact mode of action remains elusive. It is suggested that these compounds stimulate the release of arachidonic acid from membrane phospholipids, which initiates eicosanoid metabolism in mammals leading to the inhibition of thromboxane $A$ synthesis and a significant reduction in platelet aggregation and vasoconstriction [261].

In addition to inhibiting the two leading causes of death in humans, cancer and cardiovascular diseases, thiosulfides have also been shown to stimulate the immune system, by activating $T$ cell proliferation [264266], to have anti-microbial effect [267], and to reduce blood glucose level in diabetics by stimulating insulin secretion by the pancreas [268-270]. Thiosulfides appear to have also anti-asthmatic properties. This anti-inflammation activity is mediated through a suppression of cyclooxygenase reaction cascades, initiating once again the eicosanoid metabolism, leading to bronchial restriction [271].

\subsection{Flavonoids}

Flavonoids are the largest group of phenolics present in vegetables. There are more than 4000 secondary plant metabolites in the flavonoid family. Flavonoids are further classified into anthocyanins, flavonols, flavones, and isoflavonoides.

\subsubsection{Anthocianins}

Anthocyanins are one of the largest and most important groups of water-soluble pigments in most species in the plant kingdom. They are accumulated in cell vacuoles and are largely responsible for diverse pigmentation on vegetables. Anthocyanins give vegetable leaves and fruits their purple and/or red colour appearance, such as in eggplant, red cabbage, purple and black broccoli, red onion, beet, rhubarb, purple and red-skinned potato, purple sweet potato, purple corn, red lettuce, red endive, red radish, strawberry, etc. [272-274]. Anthocyanines exist mainly as glycosides and acylglycosides of anthocyanidins, usually as $\mathrm{C}_{3}$ mono-, di-, and/or trisides. Anthocyanins are implicated in many biological activities that may impact positively on human health [275]. Their use for therapeutic purposes has long been supported by epidemiological evidence, but only in recent years some of the specific, measurable pharmacological properties of isolated anthocyanin pigments have been verified by controlled in vitro, in vivo, or clinical 
research studies [275]. These pigments may reduce the risk of coronary heart disease through inhibition of platelet aggregation [276]. Anthocyanins protect in several ways. First, they neutralize enzymes that destroy connective tissue. Second, their antioxidant capacity prevents oxidants from damaging connective tissue. Finally, they repair damaged proteins in the blood-vessel walls. Anthocyanins have also been shown to protect mammalian cell lipoproteins from damage from free radicals. For example, nasunin, an anthocyanin from eggplant, has been shown to inhibit brain cell lipid peroxidation caused by oxygen and hydroxyl free radicals [277] and to reduce intestinal absorption of cholesterol [278]. In addition, anthocyanins could exert anticarcinogenic activities, reduce inflammatory insult and also modulate immune response. All these effects might be mediated by their antioxidant activity [279]. In many other cases, the exact roles of the anthocyanins in human health versus other phytochemicals have not been completely sorted out. Some reports suggest that anthocyanin activity potentates when it is delivered in mixtures [280].

\subsubsection{Flavonols}

Flavonols are polyphenolic secondary plant metabolites and exist primarily in the glycosylated form with a hydroxil group at $\mathrm{C}_{3}$ position. Flavonols include quercetin, kaempferol, fisetin, myricetin, and rutin. Quercetin is the most important flavonoid in vegetables. It has been detected in onions and to lesser extent in tomato, snap and mange-tout peas, and beans [281, 282]. Kaempferol, myricetin, and fisetin have been detected in onion, lettuce, endive, and horseradish [282-285]. The effect of flavonols on cardiovascular diseases and carginogens in human and laboratory animals has been studied by several investigators, although the health benefits of flavonols have yet to be fully established. However, they have been shown to function in a way similar to antioxidant vitamins, to protect against lipoprotein oxidation in vitro [286-288], to have anti-platelet and anti-thrombotic actions [289, 290], and to produce inhibition of estrogen binding in mammalian cells [291], and induction of the phase II enzyme quinone reductase in murine hepathoma cells [292]. Evidence obtained with an in vitro oxidation model for heart disease has demonstrated that several plant flavonols, such as quercetin, myricetin and rutin, are more powerful antioxidants than the traditional vitamins [293]. So there are grounds for encouraging the consumption of vegetables and other foods rich in flavonols.

\subsubsection{Flavones}

Similar to flavonols, flavones including apigenin and luteolin, also exist as O-glycosides with a hydrogen atom in the $\mathrm{C}_{3}$ position. Flavones have been detected in conjugated form in celery [281, 282], tomato, eggplant, garlic and onion [285, 294]. Celery contains flavones rather than flavonols, and widely varying levels of both luteolin and apigenin in different cultivars [281, 282, 285]. In recent years, scientific and public interest in flavones has grown enormously due to their putative beneficial effects against atherosclerosis, osteoporosis, diabetes mellitus and certain cancers [295]. The mechanism of action of flavones on chronic diseases is similar to that of other flavonoids. They were proposed to function primarily as antioxidants by conserving a-tocopherol content of low density lipoproteins and membrane lipids in the reduced state [295, 296], and may potentially be used as an anticancer agent for prevention and therapy of breast and other DLC1 (Deleted in Liver Cancer 1) downregulated cancers [297].

\subsubsection{Isoflavonoids}

In contrast to other flavonoids, isoflavonoids including daidzen, genistein, and glycitein have limited distribution in vegetables $[298,299]$. They exist mainly in legumes such as soybean, chickpea, lentil, and alfalfa sprouts [300-303]. Smaller quantities have also been detected in other vegetables, such as broccoli, asparagus, and okra [301, 304]. Genistein and daidzein have been found in relatively high concentrations in soybean and most soy-based foods. Much of the research on the health benefits of isoflavonoids has been done on soybean isoflavonoids daidzein and genistein [305-308]. Goldwyn et al. [305] made a review of the health benefits of isoflavonoids. In this review genistein was reported to have an estrogenic like activity at low concentration and anti-estrogenic activity at high concentration, as well as the highest affinity for binding to the estrogen receptors and/or by blocking estrogen synthesis. In contrast, daidzein has very low estrogen activity. However it is further metabolized in the large intestine into equol. Equol is a potent phytoestrogen and an antioxidant, but the rate of conversion varies among individuals, which could affect the health benefits of this compound [309].

Consumption of soy isoflavonoids has been suggested to have multiple beneficial effects in a number of chronic diseases and medical conditions, including certain types of cancer [310], heart disease [311], bone functions [312, 313] and most recently, 
prevention of obesity [314]. Estrogen-like effects have been proposed as one of the major mechanisms of action of isoflavonoids related to their health effects [315]. A second mechanism of action of isoflavonoids, particularly of genistein, was discovered that genistein is a protein tyrosine kinase inhibitor [315]. Since then, isoflavonoidses have been shown to affect a diverse array of intracellular signaling pathways [316]. As polyphenols, isoflavonoids also have antioxidant activities which were proposed as another important mechanism of action of isoflavones. However, isoflavones are not strong antioxidants since they may not be able to scavenge oxidants directly. Therefore they are considered as antioxidants because of their effects on gene expression of enzymes that enhance antioxidant defenses [317]. In addition, several other mechanisms have been proposed for the activities of isoflavonoids, including stimulation/inhibition of enzyme activities involved in steroid synthesis and metabolism, targeting thyroid peroxidase, and inhibiting cancer metastasis [317]. Lee et al. [318] and Ziegler et al. [319] found that Asian women who consumed a diet rich in soy products had relatively low risk of breast cancer. Further evaluation of soy-based diets and foods has confirmed that the main antibreast cancer ingredient is genistein [320-322]. In a most recent meta-analysis of prospective studies, it was suggested that soybean isoflavonoids intake is associated with a significantly reduced risk of breast cancer incidence in Asian populations, but not in Western populations. Further studies are warranted to confirm the finding of an inverse association of soy consumption with risk of breast cancer recurrence [323]. Epidemiological evidence together with preclinical data from animal and in vitro studies strongly supported a correlation between soybean isoflavonoids consumption and protection towards prostate cancers [321, 324]. Besides breast and prostate cancer, isoflavonoids also showed inhibitory effects on other hormone-related (e.g., endometrial, ovarian cancer) or hormoneindependent cancers (e.g., leukemia and lung cancer) [325].

\section{PHYTONUTRICEUTICALS CONTENT AND HEALTH BENEFITS OF VEGETABLES}

\subsection{Introduction}

There is an increasing awareness among the general public of the advantages of diets rich in vegetables to ensure an adequate intake of most vitamins and micronutrients, dietary fibers, and phytochemicals that promote health. All the vegetables may offer protection to humans against chronic diseases. With the exception of glucosinolates and thiosulfides, which are unique to the crucifers and alliums, the phytonutriceuticals content of a number of other vegetales consist primarily of vitamin C, fiber, selenium, folate and polyphenolics (carotenoids and flavonoids). The main difference is that each vegetable group contains a unique combination and amount of these phytonutriceuticals, which distinguishes them from other groups and vegetables whithin their own group. In this section we will highlight the health benefits of the most studied and consumed vegetables namely crucifers, alliums, solanaceous vegetables, cucurbits, legumes, and other minor vegetable families (Asteraceae, Apiaceae, Chenopodiaceae).

\subsection{Crucifers}

Cruciferous vegetables (Brassicacea or Cruciferae family) which include, cabbage, broccoli, cauliflower, Brussels sprouts, kales, kailan, Chinese cabbage, turnip, rutabaga, radish, horseradish, rocket, watercress, mustards, among other vegetables, provide the richest sources of glucosinolates in the human diet. Crucifers rich in glucosinolates including broccoli, cabbage, Brussels sprouts, and kale have been shown to protect against lung, prostate cancer, breast cancer, and chemically induced cancers [326330]. Epidemiological data show that a diet rich in crucifers can reduce the risk from several types of cancers and that the risk can be significantly reduced by an intake of at least $10 \mathrm{~g}$ per day [326, 327, 329332].

Comparative studies of glucosinolate profiles indicate significant quantitative and qualitative differences among accessions within each crucifer, between plant parts, developmental stage, agronomic management, and climatic conditions [185, 333-344]. Kushad et al. [338] observed in 65 cultivars of broccoli, that glucoraphanin was the major glucosinolate and that there was more than 27-fold difference between the highest concentration in cultivar "Brigadier" and the lowest concentration in cultivar "EV6-1". Hansen et al. [204] also observed in their study with 21 cultivars of red cabbage and 6 white cabbages, that there was a considerable variation in the concentration of the individual glucosinolates between the cultivars examined. Red cabbage cultivars were found to contain significantly higher concentrations of glucoraphanin compared to white cabbage cultivars. There were also significant differences within the red cabbage cultivars. Of the red cultivars examined 
"Rodima" had the highest concentration with $7.4 \mathrm{mg} / \mathrm{g}$ DW glucoraphanin whereas "Primero" has the lowest concentration containing only $0.6 \mathrm{mg} / \mathrm{g} \mathrm{DW}$. The white cabbage cultivars contained significantly higher levels of glucoiberin compared to red cultivars. The white cabbage cultivar "Bartolo" contained the highest level of $7.4 \mathrm{mg} / \mathrm{g}$ dry weight, whereas the cultivar "Candela" had the lowest level of $1.7 \mathrm{mg} / \mathrm{g}$ dry weight. The red cultivars ranged from approximately $3 \mathrm{mg} / \mathrm{g}$ dry weight to $0.3 \mathrm{mg} / \mathrm{g}$ dry weight. The red cabbages were also found to contain significantly higher concentration of gluconasturtiin compared to white cabbage cultivars. The cultivar "Amager Garo" had the highest concentration whereas "Primero" had the lowest, 1 and $0.1 \mathrm{mg} / \mathrm{g}$ dry weight, respectively. Similar differences were also observed in turnip and rutabagas [334]. Fahey et al. [195] evaluated glucosinolate content of broccoli sprouts and found that they contain nearly 20to 50-fold higher glucosinolates than tissue from mature plants. In broccoli heads, the most significant glucosinolates are glucoraphanin, glucobrassicin, progoitrin, and gluconasturtiin [218, 336, 338, 340-343]. In cabbage, Brussels sprouts, cauliflower, kale, tronchuda and collard the predominant glucosinolates are sinigrin, progoitrin, and glucobrassicin [204, 333, $336,338,344,345]$. In turnip and rutabagas, the predominant glucosinolates are glucoerucin, glucoraphanin, and glucobrassicin [334, 337]. In radish, the predominant glucosinolates are glucoerucin, glucoraphanin, and glucobrassicin [335, 339]. Each of these crucifers also contain smaller amounts of other glucosinolates.

Crucifer vegetables are also rich in vitamins, with kale rated as the second highest among 22 vegetables tested [346]. Brussels sprouts and broccoli were also ranked high in their vitamin content, containing significant amounts of vitamins $C$ and $E$, and $\beta$ carotene [346]. Evaluation of $\alpha-$ and $\beta-, \alpha-$, and $\gamma^{-}$ tocopherols, and vitamin $C$ in broccoli, Brussels sprouts, cabbage, cauliflower, tronchuda, and kale, showed significant variations between and within these crucifers [338, 347].Vitamin $C$ is the most abundant vitamin in all five crucifers tested [347]. Kale had the highest amount of these vitamins, followed by broccoli, Brussels sprouts, cabbage and cauliflower. Crucifers are also excellent source of folate. Brussels sprouts and broccoli were ranked among the highest vegetable sources for folate, contributing about 110 to 135 and 70 to $90 \mu \mathrm{g} / 100 \mathrm{~g}$, respectively [90, 348].

Crucifers also contain significant amounts of dietary fiber. Dietary fiber content of cauliflower was estimated to be about $5 \%$ of the total fresh weight or about $50 \%$ of the total dry weight, consisting of about $40 \%$ nonstarch polysaccharides [347]. Cellulose and lignin concentrations in Brussels sprouts were estimated to be $36 \%$ and $14.5 \%$, while in cauliflower they were estimated to be about $16 \%$ and $13 \%$ of the total dry matter, respectively [350].

There are plenty of crucifers (e.g. kales, tronchuda cabbages, pak-choy, kailan, rutabaga, turnip, Brussels sprouts, etc.). that are good sources of calcium. As mentioned Galega kale contains a high content of protein, fiber, calcium, and sulfur when compared to broccoli, the reference within Brassica vegetables. Crucifers contain very low concentrations of selenium but they are capable of accumulating substantial amounts of selenium when grown on high-selenium soil. Banuelos and Meek [48] reported that broccoli grown on selenium-enriched soil accumulated sevenfold more selenium than cabbage, collards and Swiss chard. Broccoli plants grown outdoors on a sphagnum, peat moss, and vermiculite medium and fertilized with sodium-selenate and selenite accumulated $278 \mathrm{mg} / \mathrm{g}$ dry weight selenium, in the edible florets, compared to the nonfertilized control, which accumulated only $0.13 \mathrm{mg} / \mathrm{g}$ dry weight [50]. In broccoli, selenium is stored as selenocysteine [51]. Selenium-enriched broccoli has been found to reduce colon cancer and mammary tumors in animal models $[49,52]$.

Other antioxidants in crucifers include flavonoids. Miean and Mohamed [285] examined the flavonoid content of 62 vegetables and found that broccoli, cauliflower, cabbage, Chinese cabbage, and kailan contained between 148 and $219 \mathrm{mg} / \mathrm{kg}$ of flavonoids. Broccoli contained myricetin, quercetin, and luteolin; cauliflower contained myricetin and quercetin; kailan contained quercetin and apigenin; while cabbage contained only myricetin.

\subsection{Alliums}

Alliums vegetables (Alliaceae family) include, garlic, onion, leek, chive, Welsh onion, among other vegetables. They are rich in a wide variety of thiosulfides, which have been linked to reducing various chronic diseases. Similar to glucosinolates in crucifers, the types and amounts of thiosulfides in alliums vary significantly. Kubec et al. [235] reported significant variability in the total thiosulfide $(0.02$ to $1.3 \%$ fresh weight) content and in the relative proportion of these compounds between and within 
alliums, even when grown under identical conditions. They found that the total thiosulfide contents in green onion leaves, chive, and onion bulb were $0.2,0.72$, and $1.02 \mathrm{~g} / \mathrm{kg}$ fresh weight, respectively. The type of thiosulphides in these vegetables were also variable. For example, onion bulbs contained $34 \%$ methiin, $5 \%$ ethiin, $6 \%$ propiin, $5 \%$ alliin, and $49 \%$ isoalliin [244], while garlic cloves contained about $92 \%$ alliin, $8 \%$ methiin, and trace amounts of ethiin, propiin, and isoalliin [351].

The second most important group of phytonutriceuticals in alliums are flavonoids. Two types of flavonoids are found in onion bulbs: anthocyanins in red onions and flavonols like quercetin and kaempferol in most yellow fresh cultivars. Miean and Mohamed [275] reported that onion leaves had the highest total flavonoid content among 62 different vegetables they tested and that total flavonoid content of onion leaves and garlic were about 2.7 and $1.0 \mathrm{~g} / \mathrm{kg}$ dry weight, respectively [285]. In onion leaves, about $55 \%$ of the total flavonoids is quercetin, $31 \%$ kaempferol, and $14 \%$ luteolin. In onion bulb, more than $95 \%$ of the flavonoids is quercetin and only a trace amount of kaempferol [352]. White onion cultivars were reported to have significantly less quercetin than the red ones, and most of the quercetin is present in the outer scales [353]. Red onions contained approximately $1,350 \mu \mathrm{g} / \mathrm{g}$ fresh weight of total flavonols, and white onions contained only $10 \mu \mathrm{g} / \mathrm{g}$. Quercetin in onion appeared mainly in the free-form as the aglycone [353]. In garlic cloves, $72 \%$ of the total flavonoids are myricetin, $23 \%$ apigenin, and $5 \%$ quercetin [285]. In chive, garlic chive, and leek the predominant flavonoid is kaempferol [354].

Onion and garlic are excellent sources of calcium, potassium and manganese, providing up to $10 \%$ of the human daily requirements of these elements. Onions and garlics contain very low concentrations of selenium but they can accumulate selenium if grown in seleniumrich soils in the form of selenocystein and selenoproteins. Ip and Lisk [355] reported that 'Valencia' topset garlic cloves contained $0.06 \mathrm{ppm}$ selenium, while 'Stuttgart' onion bulbs contained $0.02 \mathrm{ppm}$. Onions also contain chromium and are considered a good source of this element. Chromium has been recently linked to diabetes prevention and appears to act as such by potentiating insulin receptor kinases [356] and to be a part of the glucose tolerance factor, involved in cellular responses to insulin. Clinical studies on diabetic patients have shown that chromium can decrease fasting glucose levels, improve glucose tolerance, lower insulin levels and decrease total cholesterol and triglycerid levels. Two hundred grams of onions contain up to $20 \%$ of the daily requirements in chromium.

Onions are a rich source of dietary fibers and especially of inulin, a polyfructosan. The health benefits of inulin-type fructans to human health have now been studied for more than one decade [357]. It has prebiotic properties, as it is preferably fermented by beneficial bowel bacteria like Lactobacilli and Bifidobacteria, thereby altering the bacterial mycoflora of the intestine in such a way that pathogenic, or harmful bacteria become less abundant [358]. Neokestose, another fructan found in onion, has recently been shown to be an excellent promoter of the growth of beneficial bacteria [359]. Frutans also promote the absorption of calcium and could thus be useful in the prevention of osteoporosis [360]. High-fructan diets have also been shown to lower concentration of cholesterol, tryacylglycerol, phospholipids, glucose and insulin in the blood of middle-aged men and women [361]. Owing to the presence of prebiotic polysaccharides (inulin), which are poorly degraded by the gut enzymes, and the presence of flavonoids, onions have been shown to possess anti-diabetic potential [362].

\subsection{Solanaceous Vegetables}

Solanaceous vegetables (Solanaceae family) include very important vegetables such as tomato, potato, peppers and eggplant There are significant differences in the phytonutreucical content between these solanaceous vegetables, and therefore each vegetable will be examined separately.

\subsubsection{Tomato}

The major phytochemicals in tomato are the carotenoids consisting of 60 to $64 \%$ lycopene, 10 to $12 \%$ phytoene, 7 to $9 \%$ neurosporene, and 10 to $15 \%$ carotenes [363]. Tomatoes and tomato-based foods are the world richest sources of lycopene. Based on a fresh weight basis, tomato (on average) contains about $35 \mathrm{mg} / \mathrm{kg}$ of lycopene, with red cultivars containing in average $90 \mathrm{mg} / \mathrm{kg}$ of lycopene and yellow ones only 5 $\mathrm{mg} / \mathrm{kg}$ [364]. Processed tomatoes (sauce, paste, juice, and ketchup) contain 2- to 40-fold higher lycopene than fresh tomatoes [363-366]. Tomato contains significant amounts of $\alpha-, \quad \beta-, \quad \gamma^{-}, \quad \delta$-carotene ranging in concentrations form 0.6 to $2.0 \mathrm{mg} / \mathrm{kg}$ [367, 368], which ranks tomato as the fourth leading contributor of provitamin $\mathrm{A}$ and vitamin $\mathrm{A}$ in the American diet [89, 369]. People consuming diets rich in tomato and tomato based products, which are rich in the carotenoid 
lycopene were found to be less likely to develop stomach and rectal cancers than those who consume lesser amounts of lycopene rich vegetables [370].

In addition to lycopene, tomatoes are one of the top contributors of potassium in developed countries and in the American diet [371].

Tomato fruits are also an excellent source of ascorbic acid, about $200 \mathrm{mg} / \mathrm{kg}$, and are the major source of vitamin C next to citrus [372]. Tomato contains small but significant amounts $(1-2 \mathrm{mg} / \mathrm{kg})$ of lutein, $\alpha-, \beta$-, and $\gamma$-tocopherols, and conjugated flavonoids [367, 368, 373]. In a study of 20 tomato cultivars, total flavonoids' content ranged from 1.3 to $22.2 \mathrm{mg} / \mathrm{kg}$, with about $98 \%$ present in the skin [374]. Flavonoids in fresh tomato are present only in the conjugated form as quercetin and kaempferol [281], but processed tomato products contain significant amounts of free flavonoids [374]. Flavonoid content is affected by cultivar and culture. For example, cherry tomatoes have a markedly higher flavonoid content than standard or beef tomato cultivars, and field-grown fruits have higher flavonoid content than greenhouse-grown tomatoes [282, 374]. Tomato cultivars are available containing twice the normal vitamin $C$ (Doublerich), forty times normal vitamin A (97L97), high levels of anthocyanin (resulting in purple tomatoes), and two to four times the normal amount of lycopene (numerous available cultivars with the high crimson gene).

\subsubsection{Potato}

In general, potato is perceived only as a source of carbohydrates, but is also an excellent source of essential amino acids. Potato proteins are of a very high quality, possibly because they are rich in essential amino acids, such as lysine, and other metabolites, which may enhance protein utilization [375-377]. The lysine content of potato complements cereal-based diets, which are deficient in this amino acid.

In addition to high quality proteins, potato tubers accumulate significant amounts of vitamins and minerals, as well as an assortment of phytochemicals including phenolics, phytoalexins, and protease inhibitors. Chlorogenic acid constitutes up to $90 \%$ of the potato tuber natural phenols. Others found in potatoes are 4-O-caffeoylquinic acid (cryptochlorogenic acid), 5-O-caffeoylquinic (neo-chlorogenic acid), 3,4-dicaffeoylquinic and 3,5-dicaffeoylquinic acids [378]. A medium-size $150 \mathrm{~g}$ potato with the skin provides $27 \mathrm{mg}$ of vitamin C (45\% of the daily allowance), $620 \mathrm{mg}$ of potassium (18\% of daily allowance), $0.2 \mathrm{mg}$ vitamin B6 (10\% of daily allowance) and trace amounts of thiamin, riboflavin, folate, niacin, magnesium, phosphorus, iron, and zinc. The fiber content of a potato with skin $(2 \mathrm{~g})$ is equivalent to that of many whole grain breads, pastas, and cereals.

Potato contributes a small but significant amount of phytochemicals. Several yellow, red, and purple fleshed types with high phytochemical content have recently been introduced into the market. The purple potato has purple skin and flesh, which becomes blue once cooked. A mutation in the varieties' $P$ locus causes production of the antioxidant anthocyanin [370]. Total phenolics in potato tubers range in concentration from 0.5 to $1.7 \mathrm{~g} / \mathrm{kg}$ [380, 381]. Al-Saikhan et al. [382] reported significant differences in total phenolics among cultivars, with flesh color having no significant effect on total phenolics. Nearly $50 \%$ of the total phenolic compounds in potato are located in the peel and adjoining tissue, but decrease toward the center of the tuber [382, 383], with chlorogenic acid representing about 90 percent of the total polyphenolic content [378].

Potato tubers contain a moderate amount of vitamin $\mathrm{C}$, in the range of about 10 to $104 \mathrm{mg} / \mathrm{kg}$, depending on the cultivar and the growing season, but it declined rapidly (30 to 50 percent) during storage and cooking $[376,384,385]$. Other antioxidants found in potato include 0.5 to $2.8 \mathrm{mg} / \mathrm{kg}$ a-tocopherol, 0.13 to 0.6 $\mathrm{mg} / \mathrm{kg}$ lutein, and $1 \mathrm{mg} / \mathrm{kg} \beta$-carotene [386, 387, 388]. Potato also contributes a small amount of selenium $(0.01 \mathrm{mg} / \mathrm{kg})$ and folate $(0.35 \mathrm{mg} / \mathrm{kg})$ to the human diet [348, 389].

\subsubsection{Peppers}

There are sweet and chili hot peppers. All fresh sweet peppers are excellent sources of vitamins $\mathrm{C}, \mathrm{K}$, carotenoids, and flavonoids [390]. Red bell peppers also contain lycopene, which helps to protect against cancer and heart disease $[54,55]$. Possibly due to their vitamin $\mathrm{C}$ and beta carotene content, bell peppers have been shown to be protective against cataracts [39]. Beta-cryptoxanthin, another carotenoid in red peppers, is holding promise for helping to prevent lung cancer related to smoking and secondhand smoke. Besides being rich in many different powerfull phytochemicals, peppers provide a decent amount of fiber. Significant differences in vitamin $\mathrm{C}$ were observed between cultivars, but not between species. On average, fruits contain between 1 to $2 \mathrm{~g} / \mathrm{kg}$ vitamin $\mathrm{C}$, which is equivalent to 200 to $300 \%$ of the recommended daily 
allowance for adult men and women [391]. The level of provitamin A carotenoids ( $\alpha$ - and $\beta$-carotene) is cultivar specific. Some cultivars of chili hot pepper have as much as $12 \mathrm{mg} / \mathrm{kg}$ total carotenoids, while others are bellow the detectable level [391, 392]. Major flavonoids in the peppers are quercetin and luteolin. They are present in conjugated form and their content varies among cultivars ranging from not detectable to 800 $\mathrm{mg} / \mathrm{kg}$ [393]. When comparing the nutrient values of the different bell peppers, studies have shown that red bell peppers have significantly higher levels of nutrients than green.

Chili hot peppers have amazingly high levels of vitamins and minerals. Just $100 \mathrm{~g}$ provides (in \% of recommended daily allowance), $240 \%$ of vitamin C (ascorbic acid), 39\% of vitamin B6 (pyridoxine), 32\% of vitamin $\mathrm{A}, 13 \%$ of iron, $14 \%$ of copper, $7 \%$ of potassium [19]. Fresh chili hot peppers, red or green, are rich source of vitamin-C. One hundred grams fresh chilies provide about $143.7 \mu \mathrm{g}$ or about $240 \%$ of recommended daily allowance. Chilies are also good in B-complex group of vitamins such as niacin, pyridoxine (vitamin B6), riboflavin and thiamin (vitamin B1). These vitamins are essential in the sense that body requires them from external sources to replenish. Chili hot peppers contain a good amount of minerals like potassium, manganese, iron, and magnesium. The major phytochemicals in chili hot peppers are capsaicinoids. More than 20 capsaicinoids, belonging to two groups, capsaicin and dihydrocapsaicin, have been identified in chili hot pepper. The capsaicin in hot peppers has been shown to decrease blood cholesterol and triglycerides, boost immunity, and reduce the risk of stomach ulcers. Capsaicin has also analgesic , antibacterial, and anti-diabetic properties. It is also prescribed for bladder hypersensivity, vasomotor rhinitis, and hyperreflexia of spinal origin [394].

\subsubsection{Eggplant}

The eggplant, in addition to featuring a host of vitamins and minerals, also contains important phytochemicals, which have antioxidant activity. Phytochemicals contained in eggplant include phenolic compounds, such caffeic and chlorogenic acid, and flavonoids, such as nasunin. Nasusin or delphinidin-3(coumaroylrutinoside)-5-glucoside is the major phytochemical in eggplant. Nasunin is part of the anthocyanin purple pigment found in the peel of eggplant, purple radish, red turnip, and red cabbage [277, 278, 395]. Matsuzoe et al. [396] examined the profile of anthocyanins in several eggplant cultivars and found that nasunin represents between 70 to $90 \%$ of the total anthocyanins in the peel. Nasunin is an antioxidant that effectively scavenges reactive oxygen species, such as hydrogen peroxide, hydroxyl and superoxide, as well as inhibits the formation of hydroxyl radicals, probably by chelating ferrous ions in the Fenton reaction [277, 395].

In eggplant the predominant phenolic compound found in all cultivars tested is chlorogenic acid, which is one of the most potent free radical scavengers found in plant tissues [396]. Benefits attributed to chlorogenic acid include antimutagenic (anti-cancer), antimicrobial, anti-low density lipoproteins (bad cholesterol) and antiviral activities. Whitaker and Stommel [396] studied seven eggplant cultivars grown commercially in the United States and a diverse collection of exotic and wild eggplants from other counties. In addition to chlorogenic acid, they found 13 other phenolic acids present at significantly varying levels in the commercial cultivars, although chlorogenic acid was the predominant phenolic compound in all of them. 'Black Magic'a commercial eggplant cultivar representative of US market types was found to have nearly three times the amount of antioxidant phenolics as the other eggplant cultivars that were studied.

Eggplant fruits also contain several other antioxidants including the carotenoids lycopene, lutein, and $\alpha$-carotene, as well as the flavonoids myricetin and kaempferol [285, 397]. Total antioxidant activity of eggplant was estimated to be about $190 \mu \mathrm{mol}$ Trolox equivalent per $40 \mathrm{~g}$ serving size, which ranks it in the middle among 22 commonly consumed vegetables [375]. Eggplant is an excellent source of digestionsupportive dietary fiber and bone-building manganese. It is very good source of enzyme-catalyzing molybdenum and heart-healthy potassium. Eggplant is also a good source of bone-building vitamin $\mathrm{K}$ and magnesium as well as heart-healthy copper, vitamin C, vitamin B6, folate, and niacin [398, 399].

\subsection{Other Vegetables}

The Cucurbitaceae family (e.g., pumpkin, squash, melon, cucumber) is rich in vitamin $\mathrm{C}$, carotenoids, and tocopherols [400]. Burger et al. [401] in a survey of 350 melon accessions from different horticultural groups of Cucurbita melo observed a 50 -fold variation in ascorbic acid content, ranging from $0.7 \mathrm{mg}$ to $35.3 \mathrm{mg} / 100 \mathrm{~g}$ of fresh fruit weight. Ascorbic acid and $\beta$-carotene content ranged from 7.0 to $32.0 \mathrm{mg} / 100 \mathrm{~g}$ and 4.7 to 62.2 $\mu \mathrm{g} / 100 \mathrm{~g}$, respectively in sweet melons [402]. Bitter 
gourd (Momordica charantia) has anti-diabetic properties and can be used to ameliorate the effects of type-2 diabetes. Diet is the primary therapy for this type of diabetes and bitter gourd is particularly critical when pharmaceuticals are not available, as happens in a great part of the developing world [4].

The Fabaceae or Leguminosae family, which includes all the legumes (e.g., bean, pea, soybean, chickpea, lentils), as mature and immature seeds, are good sources of dietary fiber and isoflavonoids. Mallillin et al. [403] determined the total, soluble and insoluble fibre and fermentability characteristics of ten legumes mature seeds (mung bean, soybean, peanut, pole sitao, cowpea, chickpea, green pea, lima bean, kidney bean and pigeon pea) and concluded that the dietary fibre content ranged from 20.9 to $46.9 \mathrm{~g} / 100 \mathrm{~g}$ and that the best sources after in vitro fermentation using human faecal inoculum stimulating conditions in the human colon (as $\mathrm{mmol} / \mathrm{g} / \mathrm{fibre}$ isolate of acetate, propinate, butyrate produced after fibre fermentation measured by HPLC) were pole sitao and mung bean (acetate), kidney bean and pigeon pea, (propinate), and peanut and cowpea (butyrate). High-flavonol legumes include sugar snap peas and mange-tout, which were found to contain 98 and $145 \mu$ quercetin $/ \mathrm{g}$ respectively. As mentioned some legumes are also rich in iron. Trinidad et al. [404] determined the mineral availability in vitro of iron, zinc and calcium in ten local legumes (cowpeas, mung beans, pole sitao, chickpeas, green peas, groundnuts, pigeon peas, kidney beans, lima beans and soybeans). They found that the highest iron availability among legumes was for lima beans (9.5 (sem 0.1)) and mung bean while for zinc and calcium, the highest availability was for kidney beans (49.3 (sem 4.5)) and pigeon peas (75.1 (sem 7.1)), respectively. Groundnuts have the lowest Fe (1.3 (sem 1.1)), Zn (7.9 (sem 1.3)) and $\mathrm{Ca}$ (14.6 (sem 2.8)) availability. They concluded that mineral availability of $\mathrm{Fe}, \mathrm{Zn}$, and $\mathrm{Ca}$ from legumes differs and may be attributed to their mineral content, mineral-mineral interaction and from their phytic and tannic acid content. For example mung bean (Vigna radiata) either eaten as whole pod grains or grown to produce bean sprouts, is an important source of iron for women and children throughout South Asia [405].

The Asteraceae or Compositae family (eg., lettuce, chicory) is rich in conjugated quercetin, flavonoids, and tocopherols. Crozier et al. [282] observed sizeable variations in flavonol content with lettuce cultivars. The commonly consumed small "round" lettuce contained only $11 \mu \mathrm{g} / \mathrm{g}$ fresh weight of quercetin, and the levels in "iceberg" lettuce were even lower. In contrast, the outer leaves of "Lollo Rosso," a red cultivar of lettuce, contained $911 \mu \mathrm{g} / \mathrm{g}$. The red color of this lettuce is due to high levels of anthocyanins, which like quercetin, are products of the phenylpropanoid pathway. As one end product of the pathway has been elevated, it may well be that other related compounds, including the flavonols, are also found in higher concentrations. Romaine lettuce is richer in lutein than head lettuces; and leafy and romaine lettuces are richer in quercetin [406].

The Apiaceae family (e.g., celery, parsley, carrot) is rich in flavonoids, carotenoids, vitamin $\mathrm{C}$, and vitamin E. Celery and parsley, for example, are among the best vegetable sources for the flavonoid apigenin and vitamin E [407], and carrots have an unique combination of three flavonoids: kaempferol, quercetin, and luteolin [274, 275, 408]. In carrot, overallcarotenoid levels, have increased dramatically in the past four decades through traditional breeding to reach levels of 1,000 ppm carotenoids, on a fresh weight basis [409].

The Chenopodiaceae family (e.g., spinach, Swiss chard, beet greens) is an excellent source of folate [90] and has been shown to inhibit DNA synthesis in proliferating human gastric adenocarcinoma cells [410]. The Chenopodiaceae vegetables are also among the most oxalate dense vegetables [411, 412]. When oxalates become too concentrated in body fluids, they can crystallize and cause health problems such as kidney calcium oxalate stones.

\section{CONCLUSIONS}

Regular consumption of a vegetable rich diet has undeniable positive effects on health since phytonutriceuticals of vegetables can protect the human body from several types of chronic diseases. The mechanism by which vegetables decrease risk of disease is complex and largely unknown. Various components of the whole food are likely to contribute to the overall health benefit. Various phytonutriceuticals with antioxidant properties may work directly by quenching free radicals or indirectly by participating in cell signaling pathways sensitive to redox balance. Nutrients such as potassium contribute to blood pressure regulation. The dietary fiber content and type of different vegetables may also contribute to the overall health benefit, such as improving bowel transit, lowering cholesterol, helping manage blood glucose concentrations, and by transporting a significant amount of minerals and phytochemicals linked to the fibre matrix through the human gut. 
The health promoting phytonutriceuticals in the most studied and consumed vegetables, and their biological activity against chronic diseases, have been discussed in this article. Because each vegetable contains a unique combination of phytonutriceuticals, a great diversity of vegetables should be eaten to ensure that individual's diet includes a combination of phytonutriceuticals and to get al the health benefits. The availability of a large diversity of vegetables year round, and the knowledge of vegetable health benefits, enable consumers to include a variety of healthpromoting phytonutriceuticals in their diets.

\section{REFERENCES}

[1] Quebedeaux B, Eisa HM. Horticulture and human health. Contributions of fruits and vegetables. Proc. 2nd Intl. Symp. Hort. and Human Health. Hort Sci 1990; 25: 1473-32.

[2] Craig W, Beck L. Phytochemicals: health protective effects. Can J Diet Pract Res 1999; 60: 78-84.

[3] Wargovich MJ. Anticancer properties of fruits and vegetables. Hort Sci 2000; 35: 573-75.

[4] Dias JS, Ryder E. World vegetable industry: production, breeding, trends. Hort Rev 2011; 38: 299-56.

[5] Southon S. Increased fruit and vegetable consumption within the EU: Potential health benefits. Food Res Int 2000; 33: 211-17.

http://dx.doi.org/10.1016/S0963-9969(00)00036-3

[6] Herrera E, Jimenez R, Aruoma OI, Hercberg S, SanchezGarcia I, Fraga C. Aspects of antioxidant foods and supplements in health and disease. Nutr Rev 2009; 67(1): S140-44.

http://dx.doi.org/10.1111/j.1753-4887.2009.00177.x

[7] Prior RL, Cao G. Antioxidant phytochemicals in fruit and vegetables, diet and health implications. Hort Sci 2000; 35: 588-92.

[8] Hyson, D. The health benefits of fruit and vegetables. A scientific overview for health professionals. Produce for Better Health Foundation. Wilmington DE 2002.

[9] Golberg G, Ed. Plants: diet and health. The Report of a British Nutrition Foundation Task Force. Blackwell Science, Oxford 2003.

[10] IFAVA. Fruit, vegetables and health: a scientific overview. International fruit and vegetable Alliance, Ottawa, Canada; $2006 . \quad$ Available from: www.5aday.co.nz/5adaywebsite/cms_resources/file/Scientific $20 \%$ Overview.

[11] Keatinge JDH, Waliyar $\mathrm{F}$, Jammadass $\mathrm{RH}$, et al. Re-learning old lessons for the future of food: By bread alone no longer diversifying diets with fruit and vegetables. Crop Sci 2010; 50(1): 51-62.

[12] Pfeiffer W, McClafferty B. HarvestPlus: Breeding crops for better nutrition. Crop Sci 2007; 57: s88-105.

[13] Dias JS, Ortiz R. Transgenic vegetable crops: progress, potentials and prospects. Plant Breed Rev 2012; 35: 151-46.

[14] Ezzati F. Selected major risk factors and global and regional burden of disease. Lancet 2002; 360: 1347-60. http://dx.doi.org/10.1016/S0140-6736(02)11403-6

[15] WHO (World Health Organization). Diet, nutrition and the prevention of chronic diseases. Report of a joint WHO/FAO expert consultation. WHO Tech. Report Ser. 916 World Health Organization, Geneva, Switzerland 2003.
[16] Helen Keller International. Homestead food production model contributes to improved household food security, nutrition and female empowerment - experience from scaling-up programs in Asia (Bangladesh, Cambodia, Nepal and Philippines). Nutr Bull 2010; 8: 1-8.

[17] Kays SJ, Dias JS. Common names of commercially cultivated vegetables of the world in 15 languages. Econom Bot 1995; 49: 115-52. http://dx.doi.org/10.1007/BF02862917

[18] Kays SJ. Cultivated vegetables of the world: a multilingual onomasticon. Wageningen Academic Publishers, Wageningen, The Netherlands 2011. http://dx.doi.org/10.3920/978-90-8686-720-2

[19] Frei B, Lawson S. Vitamin C and cancer revisited. Proc Natl Acad Sci USA 2008; 105(32): 11037-38. http://dx.doi.org/10.1073/pnas.0806433105

[20] Packer L, Fuchs J, Eds. Vitamin C in health and disease. Marcel Dekker, New York 1997.

[21] Englard S, Seifter S. The biochemical functions of ascorbic acid. Annu Rev Nutr 1986; 6: 365-406.

http://dx.doi.org/10.1146/annurev.nu.06.070186.002053

[22] Levine M, Rumsey S, Wang Y, Park J, Kwon O, Xu W, Amano N. Vitamin C. In: Ziegler EE, Filer LJ Jr., Eds. Present knowledge in nutrition. 7th ed. ILSI Press, Washington DC. 1996; pp. 146-49.

[23] Jacob RA. The integrated antioxidant system. Nutr Res 1995; 15: 755-66.

http://dx.doi.org/10.1016/0271-5317(95)00041-G

[24] Halpner AD, Handelman GJ, Belmont CA, Harris JM, Blumberg JB. Protection by vitamin $\mathrm{C}$ of oxidant-induced loss of vitamin of vitamin $E$ in rat hepatocytes. J Nutr Biochem 1998; 9: 355-59.

http://dx.doi.org/10.1016/S0955-2863(98)00019-9

[25] Cuddihy SL, Parker A, Harwood DT, Vissers MC, Winterbourn CC. Ascorbate interacts with reduced glutathione to scavenge phenoxyl radicals in HL60 cells. Free Radic Biol Med 2008; 44(8): 1637-44.

http://dx.doi.org/10.1016/j.freeradbiomed.2008.01.021

[26] Valero E, Gonzalez-Sanchez MI, Macia H, Garcia-Carmona F. Computer simulation of the dynamic behavior of the glutathione-ascorbate redox cycle in chloroplasts. Plant Physiol 2009; 149(4): 1958-69. http://dx.doi.org/10.1104/pp.108.133223

[27] Foyer $\mathrm{CH}$, Noctor $\mathrm{G}$. Ascorbate and glutathione: the heart of the redox hub. Plant Physiol 2011; 155(1): 2-18. http://dx.doi.org/10.1104/pp.110.167569

[28] Dulloo RM, Mjundar S, Chakravarti RN, Mehta RN, Mahmood A. Effect of vitamin C deficiency in guinea pigs on intestinal functions and chemical composition of brush border membrane. Annu Nutr Metab 1981; 25: 213-20. http://dx.doi.org/10.1159/000176497

[29] Singh RB, Ghosh S, Niaz MA, et al. Dietary intake, plasma levels of antioxidant vitamins, and oxidative stress in relation to coronary artery disease in elderly subjects. Am J Cardiol 1995; 76: 1233-38. http://dx.doi.org/10.1016/S0002-9149(99)80348-8

[30] Gale CR, Martyn CN, Winter PD, Cooper C. Vitamin C and risk of death from stroke and coronary heart disease in cohort of elderly people. Br Med J 1995; 310: 1563-66. http://dx.doi.org/10.1136/bmj.310.6994.1563

[31] Nyyssonen K, Parviainen MT, Salonen R, Toumilehto J, Salonen JT. Vitamin C deficiency and risk of myocardial infarction: prospective population study of men from eastern Finland. Br Med J 1997; 314: 634-38. http://dx.doi.org/10.1136/bmj.314.7081.634

[32] Simon JA, Hudes ES, Brown WS. Serum ascorbic acid and cardiovascular disease prevalence in US adults. Epidemiology 1998; 9: 316-21.

http://dx.doi.org/10.1097/00001648-199805000-00017 
[33] Wassertheil-Smoller S, Romney SL, Wylie-Rosett J, Slagle S, Miller G, Lucido D, Duttagupt C, Palan PR. Dietary vitamin $\mathrm{C}$ and uterine cervical dysplasia. Am J Epidemiol 1981; 114: 714-24.

[34] Freudenheim JL, Graham S, Marshall JR, Haughey BP, Wilkinson G. A case-control study of diet and rectal cancer in western New York. Am J Epidemiol 1990; 131: 612-24.

[35] Howe GR, Benito E, Castelleto R, et al. Dietary intake of fiber and decreased risk of cancers of the colon and rectum: evidence from the combined analysis of 13 control studies. $J$ Natl Cancer Inst 1992; 84: 1887-96. http://dx.doi.org/10.1093/jnci/84.24.1887

[36] Howe GR, Jain M, Miller AB. Dietary factors and risk of pancreatic cancer: results of a Canadian population-based case-control study. Int J Cancer 1990; 45: 604-8. http://dx.doi.org/10.1002/ijc.2910450405

[37] Fontham ET, Pickle W, Haenszel W, Correa P, Lin YP, Falk RT. Dietary vitamins $A$ and $C$ and lung cancer risk in Louisiana. Cancer 1988; 62: 2267-73.

http://dx.doi.org/10.1002/1097$0142(19881115) 62: 10<2267::$ AIDCNCR2820621033>3.0.CO;2-E

[38] O'Toole P, Lombardi M. Vitamin C and gastric cancer: supplements for some or fruit for all? Gut 1996; 39: 345-7. http://dx.doi.org/10.1136/gut.39.3.345

[39] Delamere NA. Ascorbic acid and the eye. Subcell Biochem 1996; 25: 313-29. http://dx.doi.org/10.1007/978-1-4613-0325-1 16

[40] Frei BT, England L, Ames BN. Ascorbat on an outstanding antioxidant in human blood plasma. Proc Nat Acad Sci USA 1989; 86: 6377-81. http://dx.doi.org/10.1073/pnas.86.16.6377

[41] Jialal I, Vega GI, Grundy SM. Physiologic levels of ascorbate inhibit the oxidative modification of low density lipoprotein. Atherosclerosis 1990; 82: 185-91. http://dx.doi.org/10.1016/0021-9150(90)90039-L

[42] Harrison FE, May JM. Vitamin C function in the brain: vital role of the ascorbate transporter SVCT2. Free Radic Biol Med 2009; 46(6): 719-30.

http://dx.doi.org/10.1016/j.freeradbiomed.2008.12.018

[43] Bremner JD, McCaffery P. The neurobiology of retinoic acid in affective disorders. Prog Neuropsychopharmacol Biol Psychiatry 2008; 32(2): 315-31.

http://dx.doi.org/10.1016/j.pnpbp.2007.07.001

[44] WFP (World Food Programme). Annual Report. WFP- UN, Washington 2007.

[45] UNICEF. Vitamin and Mineral Deficiency. A Global Progress Report, UNICEF 2010.

[46] Britton G, Khachik F. Carotenoids in Food. In: Britton G, Pfander H, Liaaen-Jensens S, Eds. Carotenoids. Birkhäuser, Basel 2009; pp. 45-66. http://dx.doi.org/10.1007/978-3-7643-7501-0 3

[47] Olson JA. Carotenoids. In: Shils ME, Olson JA, Shick M, Ross AC, Eds. Modern nutrition in health and disease. $9^{\text {th }}$ ed. Williams \& Wilkins. Baltimore, MD 1999; pp. 525-41.

[48] Pasquali MA, Gelain DP, Zanotto-Filho A, et al. Retinol and retinoic acid modulate catalase activity in Sertoli cells by distinct and gene expression-independent mechanisms. Toxicol In Vitro 2008; 22(5): 1177-83. http://dx.doi.org/10.1016/j.tiv.2008.03.007

[49] Ramakrishn V, Jailkhani R. Oxidative stress in non-insulindependent diabetes mellitus (NIDDM) patients. Acta Diabetol 2008; 45(1): 41-6. http://dx.doi.org/10.1007/s00592-007-0018-3

[50] Botella-Carretero JI, Balsa JA, Vazquez C, Peromingo R, Diaz-Enriquez M, Escobar-Morreale HF. Retinol and alpha- tocopherol in morbid obesity and nonalcoholic fatty liver disease. Obes Surg 2010; 20(1): 69-76.

\section{http://dx.doi.org/10.1007/s11695-008-9686-5}

[51] Kao SH, Chao HT, Chen HW, Hwang TI, Liao TL, Wei YH. Increase of oxidative stress in human sperm with lower motility. Fertil Steril 2008; 89(5): 1183-90. http://dx.doi.org/10.1016/j.fertnstert.2007.05.029

[52] Michikawa T, Nishiwaki Y, Kikuchi Y, et al. Serum Levels of Retinol and Other Antioxidants for Hearing Impairment among Japanese Older Adults. J Gerontology Series-Biol Sci Med Sci 2009; 64(8): 910-15. http://dx.doi.org/10.1093/gerona/glp038

[53] Di Mascio P, Kaiser S, Sies H. Lycopene as the most effective biological carotenoid singlet oxygen quencher. Arch Biochem Biophys 1989; 274: 532-38. http://dx.doi.org/10.1016/0003-9861(89)90467-0

[54] Agarwal S, Rao AK. Tomato lycopene and its role in human health and chronic diseases. CAMJ 2000; 163(6): 739-44.

[55] Rao AV, Ed. Tomatoes, Lycopene and Human Health Preventing Chronic Diseases. Caledonian Science Press. Stranraer, Scotland 2006.

[56] Gaziano JM, Manson JE, Branch LG, Colditz GA, Willet WC, Buring JE. A prospective study of consumption of carotenoids in fruits and vegetables and decreased cardiovascular mortality in elderly. Ann Epidemiol 1995; 5: 55-60. http://dx.doi.org/10.1016/1047-2797(94)00090-G

[57] Johnson EJ, Hammond BR, Yeum KJ, et al. Relation among serum and tissue concentrations of lutein and zeaxanthin and macular pigment density. Am J Clin Nutr 2000; 71(6): 1555-62.

[58] Niizu PY, Rodriguez-Amaya DB. Flowers and leaves of Tropaeolum majus L. as rich sources of lutein. J Food Sci 2005; 70 (9): S605-9.

http://dx.doi.org/10.1111/j.1365-2621.2005.tb08336.x

[59] SanGiovanni JP, Chew EY, Clemons TE, et al. The relationship of dietary carotenoid and vitamin $A, E$, and $C$ intake with age-related macular degeneration in a case control study: AREDS Report No. 22. Arch Ophthalmol 2007; 125(9): 1225-32. http://dx.doi.org/10.1001/archopht.125.9.1225

[60] Van het Hof KH, West CE, Weststrate JA, Hautvast JG. Dietary factors that affect the bioavailability of carotenoids. $J$ Nutr 2000; 130: 503-6.

[61] Roels OA, Trout M, Dujacquier R. Carotene balances on boys in Ruanda where vitamin A deficiency is prevalent. $J$ Nutr 1958; 65: 115-27.

[62] Gartner C, Stahl W, Sies H. Lycopene is more bioavailable from tomato paste than from fresh tomato. Am J Clin Nutr 1997; 66: 116-22.

[63] Unlu NZ, Bohn T, Francis DM, Nagaraja HN, Clinton SK, Schwartz SJ. Lycopene from heat-induced cis-isomer-rich tomato sauce is more bioavailable than from all-trans-rich tomato sauce in human subjects. Br J Nutr 2007; 98: 140-6. http://dx.doi.org/10.1017/S0007114507685201

[64] Van het Hof $\mathrm{KH}$, Brouwer IA, et al. Bioavailability of lutein from vegetables in 5 times higher than that of $\beta$-carotene. Am J Clin Nutr 1999; 70: 261-68.

[65] Ravaglia G, Forti P, Lucicesare A, et al. Plasma tocopherols and risk of cognitive impairment in an elderly Italian cohort. Am J Clin Nutr 2008; 87(5): 1306-13.

[66] Atkinson J, Epand RF, Epand RM. Tocopherols and tocotrienols in membranes: a critical review. Free Radic Biol Med 2008; 44(5): 739-64

http://dx.doi.org/10.1016/j.freeradbiomed.2007.11.010

[67] Naumowicz M, Petelska AD, Figaszewski ZA. Impedance spectroscopic investigation of the interactions between 
phosphatidylethanolamine and [alpha]-tocopherol in bilayer membranes. Electrochimica Acta 2009; 54(3): 1089-94. http://dx.doi.org/10.1016/j.electacta.2008.08.051

[68] Devaraj S, Leonard S, Traber MG, Jialal I. Gammatocopherol supplementation alone and in combination with alpha-tocopherol alters biomarkers of oxidative stress and inflammation in subjects with metabolic syndrome. Free Radic Biol Med 2008; 44(6): 1203-8. http://dx.doi.org/10.1016/j.freeradbiomed.2007.12.018

[69] Grattagliano I, Palmieri VO, Portincasa P, Moschetta A, Palasciano G. Oxidative stress-induced risk factors associated with the metabolic syndrome: a unifying hypothesis. J Nutr Biochem 2008; 19(8): 491-504. http://dx.doi.org/10.1016/j.jnutbio.2007.06.011

[70] Roberts CK, Sindhu KK. Oxidative stress and metabolic syndrome. Life Sci 2009; 84(22): 705-12. http://dx.doi.org/10.1016/j.lfs.2009.02.026

[71] Chung MY, Yeung SF, Park HJ, Volek JS, Bruno RS. Dietary alpha- and gamma-tocopherol supplementation attenuates lipopolysaccharide-induced oxidative stress and inflammatory-related responses in an obese mouse model of nonalcoholic steatohepatitis. J Nutr Biochem 2010; 21(12): 1200-6.

http://dx.doi.org/10.1016/j.jnutbio.2009.10.006

[72] Sen CK, Khanna S, Roy S. Tocotrienol: the natural vitamin E to defend the nervous system?. Ann New York Acad Sci 2006a; 1031: 127-42.

http://dx.doi.org/10.1196/annals.1331.013

[73] Traber MG, Atkinson J. Vitamin E: antioxidant and nothing more. Free Radic Biol Med 2007; 43 (1): 4-15. http://dx.doi.org/10.1016/j.freeradbiomed.2007.03.024

[74] Traber MG, Packer L. Vitamin E: beyond antioxidant function. Am J Clin Nutr 1995; 62(6): 1501S-9S.

[75] Traber MG, Sies H. Vitamin $E$ in humans: demand and delivery. Ann Rev Nutr 1996; 16: 321-47. http://dx.doi.org/10.1146/annurev.nu.16.070196.001541

[76] Sen CK, Khanna S, Roy S. Tocotrienols: vitamin E beyond tocopherols. Life Sci 2006b; 78(18): 2088-98. http://dx.doi.org/10.1016/j.lfs.2005.12.001

[77] Das S, Lekli I, Das M, et al. Cardioprotection with palm oil tocotrienols: comparison of different isomers". Am J Physiol Heart and Circulatory Physiol 2008; 294(2): 970-8. http://dx.doi.org/10.1152/ajpheart.01200.2007

[78] Khanna S, Roy S, Slivka A, et al. Neuroprotective properties of the natural vitamin E a-tocotrienol. Stroke 2005; 36(10): 2258-64.

[79] Ozer NK, Boscoboniki D, Azzi A. New roles of low-density lipoproteins and vitamin $\mathrm{E}$ in the pathogenesis of atherosclerosis. Biochem Mol Biol Int 1995; 35: 117-24.

[80] Azzi A, Boscoboinik D, Marilley D, Ozer NK, Stauble B, Tasinato A. Vitamin E: a sensor and an information transducer of the cell oxidation state. Am J Clin Nutr 1995; 62: 1337S-46S.

[81] Kowdley KV, Mason JB, Meydani SN, Cornwall S, Grand RJ. Vitamin E deficiency and impaired cellular immunity related to intestinal fat malabsorption. Gastroenterology 1992; 102(6): 2139-42.

[82] Brigelius-Flohé R, Davies KJ. Is vitamin E an antioxidant, a regulator of signal transduction and gene expression, or a 'junk' food? Comments on the two accompanying papers: "Molecular mechanism of alpha-tocopherol action" by Azzi, A. and "Vitamin E, antioxidant and nothing more" by $\mathrm{M}$. Traber and J. Atkinson". Free Radic Biol Med 2007; 43(1): 23.

[83] Gey KF, Puska P. Plasma vitamins E and A inversely correlated to mortality from ischemic heart disease in crosscultured epidemiology. Ann New York Acad Sci 1989; 570: 268-82.

http://dx.doi.org/10.1111/j.1749-6632.1989.tb14926.x
[84] Dowd P, Zheng ZB. On the mechanism of the anti-clotting action of vitamin E quinone. Proc Natl Acad Sci USA 1995; 92(18): 8171-5.

http://dx.doi.org/10.1073/pnas.92.18.8171

[85] Devaraj S, Hugou I, Jialal I. Tocopherol decreases CD36 expression in human monocyte-derived macrophages. $J$ Lipid Res 2001; 42(4): 521-7.

[86] Srivastava US, Goswami T. Biochemical changes in progressive muscular dystrophy XV. Distribution of radioactive glutamate and proximate composition of various components of skeletal muscle and liver in vitamin $E$ deficient dystrophy rabbits and 129/RJ(dy/dy) mice. Expt Biol 1988; 47: 185-93.

[87] Muller DP. Vitamin E and neurological function. Review. Mol Nutr Food Res 2010; 54 (5): 710-8. http://dx.doi.org/10.1002/mnfr.200900460

[88] National Research Council (USA). Committee on Diet and Health, National Academy of Sciences. Diet and Health. National. Academies Press, Washington, DC 1989.

[89] USDA (United States Department of Agriculture) USDA National Nutrient Database for Standard Reference, Release 20. USDA; 2009. Available from: http: //www.nal.usda.gov/fnic/foodcomp/Data/SR20/nutrlist/sr20w3 09.pdf.

[90] Scott J, Releille F, Fletcher J. Folic acid and folates: the feasibility for nutritional enhancement in plant foods. J Sci Food Agr 2000; 80: 795-824. http://dx.doi.org/10.1002/(SICl)10970010(20000515)80:7<795::AID-JSFA599>3.0.CO;2-K

[91] Ames BN. DNA damage from micronutrient deficiencies is likely to be major cause of cancer. Muta Res 2001; 475: 720. http://dx.doi.org/10.1016/S0027-5107(01)00070-7

[92] Weinstein SJ, Hartman TJ, Stolzenberg-Solomon R. Nul association between prostate cancer and serum folate, vitamin B6, vitamin B12, and homocysteine. Cancer Epidem Biomarkers Prev 2003; 12(11): 1271-72.

[93] Oakley GP, Adams MJ, Dickinson CM. More folic acid for everyone, now. J Nutr 1996; 126: 751S-55S.

[94] Mulinare J, Cordero JF, Erickson JD, Berry RJ. Periconceptional use of multivitamins and the occurrence of neural tube defects. J Am Med Assoc 1988; 260(21): 3141 45

http://dx.doi.org/10.1001/jama.1988.03410210053035

[95] Milunsky A, Jick H, Jick SS, et al. Multivitamin/folic acid supplementation in early pregnancy reduces the prevalence of neural tube defects. J Am Med Assoc 1989; 262(20): 2847-52.

http://dx.doi.org/10.1001/jama.1989.03430200091032

[96] Scholl TO, Johnson WG. Folic acid: influence on the outcome of pregnancy. Am J Clin Nutr 2000; 71(5): 1295S1303 S.

[97] Quinn CT, Griener JC, Bottiglieri T, Hyland K, Farrow A, Kamen BA. Elevation of homocysteine and excitatory amino acid neurotransmitters in the CSF of children who receive methotrexate for the treatment of cancer. J Clin Oncol 1997; 15: 2800-6.

[98] Stewart CP, Christian P, Schulze KJ, Leclerq SC, West Jr $\mathrm{KP}$, Khatry SK. Antenatal micronutrient supplementation reduces metabolic syndrome in 6- to 8-year-old children in rural Nepal. J Nutr 2009; 139(8): 1575-81. http://dx.doi.org/10.3945/jn.109.106666

[99] Wilton DC, Foureur MJ. A survey of folic acid use in primigravid women. Women Bir J Austral Coll Midwives 2010; 23(2): 67-73.

http://dx.doi.org/10.1016/j.wombi.2009.09.001

[100] Mason JB. Folate and colonic carcinogenesis: searching for a mechanistic understanding. J Nutr Biochem 1994; 5: 170-5. http://dx.doi.org/10.1016/0955-2863(94)90068-X 
[101] Sanjoaquin MA, Allen N, Couto E, Roddam AW, Key TJ. Folate intake and colorectal cancer risk: a meta-analytical approach. Int J Cancer 2005; 113 (5): 825-8. http://dx.doi.org/10.1002/ijc.20648

[102] Blount BC, Mack MM, Wehr C, et al. Folate deficiency causes uracil misincorporation into human DNA and chromosome breakage: implications for cancer and neuronal damage. Proc Natl Acad Sci USA 1997; 94: 3290-5. http://dx.doi.org/10.1073/pnas.94.7.3290

[103] Imasa MS, Gomez NT, Nevado Jr JB. Folic acid-based intervention in non-ST elevation acute coronary syndromes. Asian Cardiov Thoracic Ann 2009; 17(1): 13-21.

[104] Terwecoren A, Steen E, Benoit D, Boon P, Hemelsoet D. Ischemic stroke and hyperhomocysteinemia: truth or myth?. Acta Neurologica Belgica 2009; 109(3): 181-8.

[105] Bazzano LA. Folic acid supplementation and cardiovascular disease: the state of the art. Am J Med Sci 2009; 338(1): 489. http://dx.doi.org/10.1097/MAJ.0b013e3181aaefd6

[106] Bazzano LA. No effect of folic acid supplementation on cardiovascular events, cancer or mortality after 5 years in people at increased cardiovascular risk, although homocysteine levels are reduced. Evidence-Based Med $2011 ; 16(4)$ : 117-8.

http://dx.doi.org/10.1136/ebm1204

[107] Johansson M, Appleby PN, Allen NE, et al. Circulating concentrations of folate and vitamin B12 in relation to prostate cancer risk: results from the European Prospective Investigation into Cancer and Nutrition study. Cancer Epidem Biomar Prev 2008; 17(2): 279-85.

http://dx.doi.org/10.1158/1055-9965.EPI-07-0657

[108] Figueiredo JC, Grau MV, Haile RW, et al. Folic acid and risk of prostate cancer: results from a randomized clinical trial. J Natl Cancer Inst 2009; 101(6): 432-5. http://dx.doi.org/10.1093/jnci/djp019

[109] Ulrich CM. Folate and cancer prevention: a closer look at a complex picture. Am J Clin Nutr 2007; 86(2): 271-3.

[110] Dawson-Hughes B, Harris SS, Krall EA, Dallal GE. Effect of calcium and vitamin $\mathrm{D}$ supplementation on bone density in men and women 65 years of age or older. N Engl J Med 1997; 337(10): 670-6. http://dx.doi.org/10.1056/NEJM199709043371003

[111] Ross AC, Taylor CL, Yaktine AL, Del Valle HB. Eds. Dietary Reference Intakes for Calcium and Vitamin D. Institute of Medicine. Food and Nutrition Board. Committee to Review Dietary Reference Intakes for Vitamin D and Calcium. National Academies Press. Washington, DC 2011.

[112] Bihl G, Meyers A. Recurrent renal stone disease-advances in pathogenesis and clinical management. Lancet 2001; 358: 651-6.

http://dx.doi.org/10.1016/S0140-6736(01)05782-8

[113] Hall WD, Pettinger M, Oberman A. Risk factors for kidney stones in older women in the Southern United States. Am J Med Sci 2001; 322(1): 12-8. http://dx.doi.org/10.1097/00000441-200107000-00003

[114] Raboy V. Seeds for a better future: low phytic grains help to overcome malnutrition and reduce pollution. Trends Plant Sci 2001; 6: 458-62.

http://dx.doi.org/10.1016/S1360-1385(01)02104-5

[115] Institute of Medicine. Dietary reference intakes: the essential guide to nutrient requirements. National Academies Press. Washington, DC; 2006.

[116] Grases F, Simonet BM, Vucenik I, Prieto RM, Costa-Bauza A, March JG, Shamsuddin AM. Absorption and excretion of orally administered inositol hexaphosphate (IP(6) or phytate) in humans. Biofactors 2001; 15: 53-61. http://dx.doi.org/10.1002/biof.5520150105
[117] Dias JS. The Portuguese tronchuda cabbage and galega kale landraces: a historical review. Genet Resour Crop Evol 1995; 42: 179-94. http://dx.doi.org/10.1007/BF02539521

[118] Monteiro AA, Rosa E. Caldo verde: a story of Portuguese brassicas. Chronica Horticulturae 2008; 38(1): 9-11.

[119] Nelson DL, Cox MM. Lehninger, Principles of Biochemistry. $4^{\text {th }}$ Ed. W.H. Freeman and Company, New York 2005.

[120] Guerrera MP, Volpe SL, Mao JJ. Therapeutic uses of magnesium. Am Fam Physician 2009; 80(2): 157-62.

[121] Bartlett HE, Eperjesi F. Nutritional supplementation for type 2 diabetes: a systematic review. Ophthalmic Physiol Opt 2008; 28(6): 503-23.

http://dx.doi.org/10.1111/j.1475-1313.2008.00595.x

[122] Kim DJ, Xun P, Liu K, et al. Magnesium intake in relation to systemic inflammation, insulin resistance, and the incidence of diabetes. Diabetes Care 2010; 33(12): 2604-10. http://dx.doi.org/10.2337/dc10-0994

[123] Johnson S. The multifaceted and widespread pathology of magnesium deficiency. Med Hypotheses 2001; 56(2): 16370.

http://dx.doi.org/10.1054/mehy.2000.1133

[124] Champagne CM. Magnesium in hypertension, cardiovascular disease, metabolic syndrome, and other conditions: a review. Nutr Clin Pract 2008; 23(2): 142-51. http://dx.doi.org/10.1177/0884533608314533

[125] Eby GA, Eby KL. Magnesium for treatment-resistant depression: a review and hypothesis. Med Hypothesis 2010; 74(4): 649-60. http://dx.doi.org/10.1016/j.mehy.2009.10.051

[126] Hijazi N, Abalkhail B, Seaton A. Diet and childhood asthma in a society in transition: a study in urban and rural Saudi Arabia. Thorax 2000; 55: 775-9.

http://dx.doi.org/10.1136/thorax.55.9.775

[127] Ciarallo L, Brousseau D, Reinert S. Higher-dose intravenous magnesium therapy for children with moderate to severe acute asthma. Arch Ped Adol Med 2000; 154(10): 979-83.

[128] Bo S, Pisu E. Role of dietary magnesium in cardiovascular disease prevention, insulin sensitivity and diabetes. Curr Opin Lipidol 2008; 19(1): 50-6. http://dx.doi.org/10.1097/MOL.0b013e3282f33ccc

[129] Abdelwahab M, Youssef S, Aly A, Elfiki S, Elenany N, Abbas M. A simple calibration of a whole-body counter for the measurement of total body potassium in humans. Int $\mathrm{J}$ Radiat Applic Instrumen Part A Appl Radiat Isotopes 1992; 43(10): $1285-9$. http://dx.doi.org/10.1016/0883-2889(92)90208-V

[130] Campbell N. Biology. Benjamin/Cummings Pub. Co. Menlo Park, California 1987.

[131] D'Elia L, Barba G, Cappuccio F, Strazzullo P. Potassium intake, stroke, and cardiovascular disease: a meta-analysis of prospective studies. Coll Cardiol 2011; 57(10): 1210-9. http://dx.doi.org/10.1016/j.jacc.2010.09.070

[132] Slonim AD, Pollack MM. Potassium. Pediatric critical care medicine. Williams \& Wilkins, Lippincott 2006.

[133] WHO (World Health Organization). Worldwide prevalence of anaemia 1993-2005 WHO global database on anaemia. Benoist B, McLean E, Ines Egli I, Cogswell M, Eds. WHO, Geneva, Switzerland 2008.

[134] Milman N. Serum ferritin in Danes: studies of iron status from infancy to old age, during blood donation and pregnancy. Int J Hematol 1996; 63 (2): 103-35. http://dx.doi.org/10.1016/0925-5710(95)00426-2

[135] Hoppe M, Hulthén L, Hallberg L. The relative bioavailability in humans of elemental iron powders for use in food fortification. Eur J Nutr 2005; 45(1): 37-44. http://dx.doi.org/10.1007/s00394-005-0560-0 
[136] Pineda O, Ashmead HD. Effectiveness of treatment of irondeficiency anemia in infants and young children with ferrous bis-glycinate chelate. Nutrition 2001; 17(5): 381-4. http://dx.doi.org/10.1016/S0899-9007(01)00519-6

[137] Haddad EH, Berk LS, Kettering JD, Hubbard RW, Peters WR. Dietary intake and biochemical, hematologic, and immune status of vegans compared with nonvegetarians. Am J Clin Nutr 1999; 70: 586S-93S.

[138] Obeid R, Geisel J, Schorr H. The impact of vegetarianism on some haematological parameters. Eur J Haematol 2002; 69: 275-9.

http://dx.doi.org/10.1034/j.1600-0609.2002.02798.x

[139] Hallberg L. Bioavailability of dietary iron in man. Ann Rev Nutr 1981; 1: 123-47. http://dx.doi.org/10.1146/annurev.nu.01.070181.001011

[140] Gleerup A, Rossander Hulthen L, Gramatkovski E. Iron absorption from the whole diet: comparison of the effect of two different distributions of daily calcium intake. Am J Clin Nutr 1995; 61: 97-104.

[141] Hambidge KM, Krebs NF. Zinc deficiency: a special challenge. J Nutr 2007; 137(4): 1101-5.

[142] Broadley MR, White PJ, Hammond JP, Zelko I, Lux A. Zinc in plants. New Phytol 2007; 173(4): 677-702.

http://dx.doi.org/10.1111/j.1469-8137.2007.01996.x

[143] Brandt EG, Hellgren M, Brinck T, Bergman T, Edholm O. Molecular dynamics study of zinc binding to cysteines in a peptide mimic of the alcohol dehydrogenase structural zinc site. Phys Chem Chem Phys 2009; 11(6): 975-83. http://dx.doi.org/10.1039/b815482a

[144] Prasad AS. Zinc deficiency: has been known of for 40 years but ignored by global health organisations. Br Med J 2003; 326: 409-10.

http://dx.doi.org/10.1136/bmj.326.7386.409

[145] WHO. The impact of zinc supplementation on childhood mortality and severe morbidity. World Health Organization, Geneva, Switzerland; 2007. Available from: http: //www.who.int/child_adolescent_health/documents/zinc_mort ality/en/index.html.

[146] Shrimpton R, Gross R, Darnton-Hill I, Young M. Zinc deficiency: what are the most appropriate interventions? $\mathrm{Br}$ Med J 2005; 330: 347-9. http://dx.doi.org/10.1136/bmj.330.7487.347

[147] Ensminger $\mathrm{AH}$, Konlande JE. Foods \& Nutrition Encyclopedia. $2^{\text {nd }}$ ed. CRC Press. Boca Raton, Florida 1993.

[148] Freeland-Graves JH, Bodzy PW, Epright MA. Zinc status of vegetarians. J Am Dietetic Assoc 1980; 77: 655-61.

[149] Rayman MP. The importance of selenium to human health. Lancet 2000; 356: 233-41. http://dx.doi.org/10.1016/S0140-6736(00)02490-9

[150] Esaki N, Nakamura T, Tanaka H, Soda K. Selenocysteine lyase, a novel enzyme that specifically acts on selenocyteine. Mammalian distribution and purification and properties of pig liver enzyme. J Biol Chem 1982; 257: 4386-91.

[151] Swanson CA, Patterson BH, Levander OA, et al. Human [74Se]selenomethionine metabolism: a kinetic model. Am J Clin Nutr 1991; 54: 917-26.

[152] Lane HW, Medina D. Mode of action of selenium inhibition of 7, 12dimethylbenz[a]anthrancene-induced mouse mammary tumorogenesis. J Natl Cancer Inst 1985; 75: 674-9.

[153] Ip C. Chemopreventive role of selenium in carcinogenesis. J Am Coll Toxicol 1986; 5: 7-20. http://dx.doi.org/10.3109/10915818609140732

[154] Burguera JL, Burguera M, Gallignani M, Alarcón OM, Burguera JA. Blood serum selenium in the province of Mérida, Venezuela, related to sex, cancer incidence and soil selenium content. J Trace Elements Electrolytes Health Dis 1990; 4(2): 73-7.
[155] Russo MW, Murray SC, Wurzelmann JI, Woosley JT, Sandler RS. Plasma selenium levels and the risk of colorectal adenomas. Nutr Cancer 1997; 28(2): 125-9. http://dx.doi.org/10.1080/01635589709514563

[156] Knekt $P$, Marniemi J, Teppo L, Heliövaara M, Aromaa A. Is low selenium status a risk factor for lung cancer?. Am J Epidem 1998; 148(10): 975-82.

http://dx.doi.org/10.1093/oxfordjournals.aje.a009574

[157] Young KJ, Lee PN. Intervention studies on cancer. Eur J Cancer Prev 1999; 8(2): 91-103.

http://dx.doi.org/10.1097/00008469-199904000-00003

[158] Helzlsouer KJ, Alberg AJ, Norkus EP, Morris JS, Hoffman SC, Comstock GW. Prospective study of serum micronutrients and ovarian cancer. J Natl Cancer Inst 1996; 88: 32-7. http://dx.doi.org/10.1093/jnci/88.1.32

[159] Yoshizawa K, Willett WC, Morris SJ, et al. Study of prediagnostic selenium level in toenails and the risk of advanced prostate cancer. J Natl Cancer Inst 1999; 90: 1219-24. http://dx.doi.org/10.1093/jnci/90.16.1219

[160] Clark LC, Combs GF, Turnbull BW. Effects of selenium supplementation for cancer prevention in patients with carcinoma of the skin. A randomized controlled trial. Nutritional Prevention of Cancer Study Group. JAMA 1996; 276(24): 1957-63. http://dx.doi.org/10.1001/jama.1996.03540240035027

[161] Tsavachidou D, McDonnell TJ, Wen S. Selenium and Vitamin E: Cell Type- and Intervention-Specific Tissue Effects in Prostate Cancer. Nat Cancer Instit 2009; 101(5): 306-20. http://dx.doi.org/10.1093/inci/djn512

[162] Overcast JD, Ensley AE, Buccafusco CJ, et al. Evaluation of cardiovascular parameters of a selenium-based antihypertensive using pulsed Doppler ultrasound. J Cardiovasc Pharmacol 2001; 38: 337-46. http://dx.doi.org/10.1097/00005344-200109000-00002

[163] Knekt P, Heliovaara M, Aho K, Alfthan G, Marniemi J, Aromaa A. Serum selenium, serum alpha-tocopherol, and the risk of rheumatoid arthritis. Epidemiology 2000; 11: 4025. http://dx.doi.org/10.1097/00001648-200007000-00007

[164] Keshan Disease Research Group. Observation on effect of sodium selenite in prevention of Keshan disease. China Med J 1979; 92: 471-6.

[165] Yang GQ, Ge RK, Chen J, Chen X. Selenium-related endemic diseases and the daily selenium requirement of humans. World Rev Nutr Diet 1988; 55: 98-152.

[166] Moreno-Reyes R, Mathieu J, Vanderpas M, et al. Selenium and iodine supplementation of rural Tibetan children affected by Kashin-Beck osteoarthropathy. Am J Clin Nutr 2003; 78(1): 137-44.

[167] Mazokopakis EE, Papadakis JA, Papadomanolaki MG, et al. Effects of 12 months treatment with L-selenomethionine on serum anti-TPO Levels in Patients with Hashimoto's thyroiditis. Thyroid 2007; 17 (7): 609-12. http://dx.doi.org/10.1089/thy.2007.0040

[168] Mueller A, Pallauf $\mathrm{J}$. Compendium of the antidiabetic effects of supranutritional selenate doses. In vivo and in vitro investigations with type II diabetic $\mathrm{db} / \mathrm{db}$ mice. J Nutr Biochem 2006; 17: 548-60. http://dx.doi.org/10.1016/j.jnutbio.2005.10.006

[169] Bleys J, Navas-Acien A, Guallar E. Serum selenium and diabetes in U.S. adults. Diabet Care 2007; 30: 829-34. http://dx.doi.org/10.2337/dc06-1726

[170] Laclaustra M, Navas-Acien A, Stranges S, Ordovas JM, Guallar E. Serum selenium concentrations and diabetes in U.S. adults: National Health and Nutrition Examination Survey (NHANES) 2003-2004. Environ. Health Perspect 2009; 117: 1409-13. 
[171] Akbaraly TN, Arnaud J, Rayman MP, et al. Plasma selenium and risk of dysglycemia in an elderly French population: Results from the prospective Epidemiology of Vascular Aging Study. Nutr Metabolism 2010; 7: 21-8.

http://dx.doi.org/10.1186/1743-7075-7-21

[172] Dreher ML. Dietary fiber overview. In: Cho SS, Dreher ML, Eds. Handbook of dietary fiber. Marcel Dekker, New York 2001.

http://dx.doi.org/10.1201/9780203904220.pt1

[173] Anderson JW, Deakins DA, Floore TL, Smith BM, Whitis SE. Dietary fiber and coronary heart disease. Crit Rev Food Sci Nutr 1990; 29: 95-147. http://dx.doi.org/10.1080/10408399009527518

[174] Anderson JW, Bridges SR. Dietary fiber content of selected foods. Am J Clin Nutr 1988; 47: 440-47.

[175] Buttriss JL, Stokes CS. Dietary fibre and health: An overview. Nutr Bull 2008; 33(3): 186-200. http://dx.doi.org/10.1111/j.1467-3010.2008.00705.x

[176] Marlett JA. Content and composition of dietary fiber in 117 frequently consumed foods. J Am Diet Assoc 1992; 92: 17586

[177] Blundell JE, Burley VJ. Satiation, satiety and the action of fibre on food intake. Int J Obes 1987; 11: 9-25

[178] Harold M, Reeves R, Blze M, Guthrie R, Guthrie D. Effect of dietary fiber in insulin-dependent diabetics: insulin requirements and serum lipids. J Am Diet Assoc 1985; 85: 1455-61.

[179] Rouse LL, Beilin LJ, Armstrong BK, Vandongen R. Blood pressure lowering effect of a vegetarian diet: controlled trial in normotensive subjects. Lancet 1983; 1: 5-10. http://dx.doi.org/10.1016/S0140-6736(83)91557-X

[180] Le Marchand L, Hankin JH, Wilksens LR, Kolonel LN, Englyst HN, Lyu LC. Dietary fiber and colorectal cancer risk. Epidemiology 1997; 8: 658-65.

[181] Slavin JL. Resistant oligosaccharides. In: Cho SS, Drecher $\mathrm{ML}$, Eds. Handbook of dietary fiber. Marcel Dekker, New York 2001; pp.125-45

[182] Saura-Calixto F, Goñi I. Antioxidant capacity of the Spanish Mediterranean diet. Food Chem 2006; 94(3): 442-47. http://dx.doi.org/10.1016/j.foodchem.2004.11.033

[183] Saura-Calixto F, Serrano J, Goñi I. Intake and bioaccessibility of total polyphenols in a whole diet. Food Chem 2007; 101(2): 492-501.

http://dx.doi.org/10.1016/j.foodchem.2006.02.006

[184] Rohdman EE. A taxonomic analysis of glucosinolate producing plants, part 1. Phenetics. Syst Bot 1991; 16: 59818. http://dx.doi.org/10.2307/2418864

[185] Fahey JW, Zalcmann AT, Talalay P. The chemical diversity and distribution of glucosinolates and isothiocyanates among plants. Phytochemistry 2001; 56: 5-51.

http://dx.doi.org/10.1016/S0031-9422(00)00316-2

[186] Wright AS. The role of metabolism in chemical mutagenesis and chemical carcinogenesis. Mutation Res 1980; 75: 21523.

http://dx.doi.org/10.1016/0165-1110(80)90017-2

[187] Holst B, Williamson G. A critical review of the bioavailability of glucosinolates and related compounds. Nat Product Reports 2004; 21 : 425-47. http://dx.doi.org/10.1039/b204039p

[188] Zhang Y, Talalay P. Anticarcinogenic activities of organic isothiocyanate: chemistry and mechanisms. Cancer Res 1994; 54: 1976s-81s.

[189] Mithen R, Faulkner K, Magrath R, Rose P, Williamson G, Marquez J. Development of isothiocyanate enriched broccoli and its enhanced ability to induce phase 2 detoxification enzymes in mammalian cells. Theor Appl Gen 2003; 106: 727-34.
[190] Fenewick GR, Heaney RK, Mullin J. Glucosinolates and their break down products in food and food plants. CRC Crit Rev Food Sci Nutr 1983; 18: 123-201. http://dx.doi.org/10.1080/10408398209527361

[191] Verkerk R, Knol JJ, Dekker M. The effect of steaming on the glucosinolate content in broccoli. Acta Hort 2010; 867: 37-45.

[192] Campbell LD, Slominski BA, Nugon-Baudon L, et al. Studies on intestinal tract glucosinolate content, xenobiotic metabolizing enzymes and thyroid status in germ-free and conventional rats fed rapeseed meal. Proc $9^{\text {th }}$ Int Rapeseed Congr 1995; 1 : 212-4.

[193] Rosa EAS, Heaney RK, Fenewick GR, Portas CAM Glucosinolates in crop plants. Hort Rev 1997; 19: 99-215.

[194] Conaway CC, Jiao D, Chung FL. Inhibition of rat liver cytochrome p 450 isozymes by isothiocyanates and their conjugates: a structure activity relationship study. Carcinogenesis 1996; 17: 2423-7. http://dx.doi.org/10.1093/carcin/17.11.2423

[195] Fahey JW, Zhang YS, Talalay P. Broccoli sprouts: an exceptionally rich source of inducers of enzymes that protects against chemical carcinogens. Proc Natl Acad Sci USA 1997; 94: 10367-72.

http://dx.doi.org/10.1073/pnas.94.19.10367

[196] Smith TK, Lund EK, Parker ML, Clarke RJ, Johnson IT. Allyl isothiocyanate causes mitotic block, loss of cell adhesion and disrupted cytoskeletal structure in HT 29 cells. Carcinogenesis 2004; 25: 1409-15. http://dx.doi.org/10.1093/carcin/bgh149

[197] Palaniswamy UR, McAvoy RJ, Bible BB, Stuart JD. Ontogenic variations of ascorbic acid and phenethyl isothiocyanate concentrations in watercress (Nasturtium officianale R.Br.) leaves. J Agri Food Chem 2003; 51: 55049. http://dx.doi.org/10.1021/jf034268w

[198] Ribnicky DM, Poulev A, Henry E, Raskin J. Seed of Barbarea verna as a rich source of phenethyl isothiocyanate to provide natural protection from environmental and dietary toxins. $J$ Nutrac Funct Med Foods 2001; 3: 43-65.

http://dx.doi.org/10.1300/J133v03n03 03

[199] Morse MA, Zu H, Galati AJ, Schmidt CJ, Stoner GD. Dose related inhibition by dietary phenethyl isothiocyanate of esophageal tumorigenesis and DNA methylation induced by $\mathrm{N}$-nitrosomethylbenzylamine in rats. Cancer Lett 1993; 72 : 103-10.

http://dx.doi.org/10.1016/0304-3835(93)90018-5

[200] Stoner GD, Morse MA. Isothiocyanates as inhibitors of esophageal cancer. Adv Exp Med Biol 1996; 401: 13-23. http://dx.doi.org/10.1007/978-1-4613-0399-2 2

[201] Hecht SS. Chemoprevention of lung cancer by isothiocyanates. Adv Exp Med Biol 1996; 401: 1-11. http://dx.doi.org/10.1007/978-1-4613-0399-2 1

[202] Hwang ES, Jeffery EH. Induction of quinone reductase by sulforaphane $\mathrm{N}$-acetyl cystein conjugate and in murine hepatoma cells. J Med Food 2005; 8: 198-203. http://dx.doi.org/10.1089/jmf.2005.8.198

[203] Khor TO, Hu R, Shen G, et al. Pharmacogenomics of cancer chemo preventive isothiocyanate compound sulforaphane in the intestinal polyps of Apc Min/+ mice. Biopharm Drug Dispos 2005; 27: 407-20. http://dx.doi.org/10.1002/bdd.522

[204] Hansen M, Bengtsson GB, Borge GI, Berge L, Wold AB. Red cabbage, a vegetable rich in health-related glucosinolates. Acta Hort 2010; 867: 61-5.

[205] Fimognari C, Nusse M, Cesari R, Iori R, Cantelli-Forti G, Hrelia P. Growth inhibition, cell cycle arrest and apoptosis in human T-cell leukaemia by the isothiocyanates sulphoraphane. Carcinogenesis 2002; 23: 581-6. http://dx.doi.org/10.1093/carcin/23.4.581 
[206] Zhang Y, Kensler TW, Cho CG, Posner GH, Talalay P. Anti carcinogenic activities of sulforaphane and structurally related synthetic norbornyl isothiocyanate. Proc Natl Acad Sci USA 1994; 91 : 3147-50.

http://dx.doi.org/10.1073/pnas.91.8.3147

[207] Talalay P, Fahey JW, Holtzclaw WD, Prestera T, Zhang Y. Chemo protection against cancer by phase 2 enzyme induction. Toxicol Lett 1995; 82: 173-9. http://dx.doi.org/10.1016/0378-4274(95)03553-2

[208] Talalay P, Zhang Y. Chemoprotection against cancer by isothiocyanate and glucosinolates. Biochem Soc Trans 1996; 24: $806-10$

[209] Thejass P, Kuttan G. Augmentation of natural killer cell and antibody dependent cellular cytotoxicity in BALB/c mice by sulforphane, a naturally occurring isothiocyanate from broccoli $1 \mathrm{~L}-2$ and IFN-gamma. Immunnopharmacol Immunnotoxicol 2006; 28: 443-57. http://dx.doi.org/10.1080/08923970600928049

[210] Wang LJ, Giovannucci EL, Hunter D, Neuberg D, Su L, Christiani DC. Dietary intake of Cruciferous vegetables glutathione -S- transferase (GST) polymorphisms and lung cancer risk in a Caucasian population. Cancer Causes Control 2004; 15: 977-85.

http://dx.doi.org/10.1007/s10552-004-1093-1

[211] Jongen WMF. Glucosinolates in brassica: occurrence and significance as cancer modulating agents. Proc Nutr Soc 1996; 55: 433-46.

http://dx.doi.org/10.1079/PNS19960040

[212] Yuan F, Chend DZ, Liu K, Sepkovic DW, Bradlow HL, Auborn K. Anti estrogenic activities of indole-3-carbinol in cervical cell: Implication for prevention of cervical cancer. Anticancer Res 1999; 19: 1673-80.

[213] Ashok BT, Chen Y, Liu X, Bradlow HL, Mittelman A, Tiwari RK. Abrogation of estrogen mediated cellular and biochemical effects by indole -3-carbinol. Nutr Cancer 2001; 41: $180-7$

[214] Ashok BT, Chen Y, Liu X, et al. Multiple molecular targets of indole-3-carbinol: a chemo preventive anti estrogen in breast cancer. Eur J Cancer Prev 2002; 11: S86-S93.

[215] Aggarwal BB, Ichikawa $\mathrm{H}$. Molecular targets and anti cancer potential of indole-3-carbinol and its derivative. Cell Cycle 2005; 4: 1201-15.

http://dx.doi.org/10.4161/cc.4.9.1993

[216] Firestone GL, Bjeldanes LF. Indole-3-carbinol and 3',3'diindolylmethane anti-proliferative signalling pathways control cell cycle gene transcription in human breast cancer cells by regulating promoter $\mathrm{sp}-1$ transcription factor interactions. J Nutr 2003; 133: 2448S-55S.

[217] Wu HT, Lin SH, Chen YH. Inhibition of cell proliferation and in vitro markers of angiogenesis by indole-3-carbinol a major indole metabolite present in Cruciferous vegetables. J Agric Chem 2005; 53: 5164-9.

http://dx.doi.org/10.1021/jf050034w

[218] Goodrich RM, Anderson JL, Stoewsand G. Glucosinolate changes in blanched broccoli and Brussels sprouts. J Food Proc Preserv 1989; 13: 275-80.

http://dx.doi.org/10.1111/j.1745-4549.1989.tb00106.x

[219] Rosa EAS, Heaney RK. The effect of cooking and processing on the glucosinolate content: studies on four varieties of Portuguese cabbage an hybrid white cabbage. J Sci Food Agric 1993; 62: 259-65. http://dx.doi.org/10.1002/jsfa.2740620309

[220] Vallejo F, Tomás-Barberán FA, Garcia-Viguera C. Glucosinolates and vitamin C contente in edible parts of broccoli inflorescences after domestic cooking. Eur Food Res Technol 2002b; 215: 310-6.

http://dx.doi.org/10.1007/s00217-002-0560-8
[221] Verkerk R, Dekker M. Glucosinolates and myrosinase activity in red cabbage (Brassica oleracea L. 'capitata' f. rubra DC.) after various microwave treatments. J Sci Food Chem 2004; 52: 7318-23.

[222] Desjardins $Y$. Onions as a nutraceutical and functional food. Chron Hort 2008; 48(2): 8-14.

[223] Nencini C, Cavallo F, Capasso A, Franchi GG, Giorgio G, Micheli L. Evaluation of antioxidative properties of Allium species growing wild in Italy. Phytother Res 2007; 21(9): 874-8. http://dx.doi.org/10.1002/ptr.2168

[224] Verma SK, Verma D. Garlic - "The spice of life": composition, cooking, chemistry and preparations. J Herbal Med Toxicol 2008; 2(2): 21-8.

[225] Kalra N, Arora A, Shukla Y. Involvement of multiple signaling pathways in diallyl sulfide mediated apoptosis in mouse skin tumors. Asian Pacific J Cancer Prev 2006; 7(4): 556-562.

[226] Rose P, Whiterman M, Moore PK, Zhu YZ. Bioactive Salk(en)yl cysteine sulfoxide metabolites in the genus Allium: the chemistry of potential therapeutic agents. Nat Prod Rep 2005; 22: 351-68. http://dx.doi.org/10.1039/b417639c

[227] Rubec R, Svobodovaand M, Velisek J. Gas chromatographic determination of S-alk(en)yl-L-cysteine sulfoxides. J Chromatogr 1999; 862: 85-94. http://dx.doi.org/10.1016/S0021-9673(99)00902-4

[228] Thomas DJ, Parkin KL. Quantification of alk(en)yl-L-cysteine sulfoxide and related amino acids in alliums by highperformance liquid chromatography. J Agr Food Chem 1994; 42: $1632-8$ http://dx.doi.org/10.1021/jf00044a010

[229] Block E, Naganathan S, Putnamand D, Zhao SH. Allium chemistry: HPLC-analysis of thiosulfinates from onion, garlic, wild garlic (ramsons), leek, scallion, shallot, elephant (greatheaded) garlic, chiveand Chinese chive: uniquely high allyl-to methyl ratios in some garlic samples. J Agr Food Chem 1992a; 40: 21418-30. http://dx.doi.org/10.1021/jf00024a017

[230] Breu W. Allium cepa (onion). Part 1: Chemistry and analysis. Phytomedicine 1996; 3: 293-306. http://dx.doi.org/10.1016/S0944-7113(96)80069-9

[231] Calvey EM, Matusik JE, White KD, DeOrazio R, Shaand D, Block E. Allium chemistry: Supercritical fluid Extraction and LD-APCI-MS of thiosulfinatesand related compounds from homogenates of garlic, onion, ramp. Identication in garlic and ramp and synthesis of 1-propanesulfinothionic acid S-allyl ester. J Agr Food Chem 1997; 45: 4406-13. http://dx.doi.org/10.1021/jf970314e

[232] Yin M, Hwang S, Chan K. Nonenzymatic antioxidant activity of four organosulfur compounds derived from garlic. J Agric Food Chem 2002; 50: 6143-7. http://dx.doi.org/10.1021/jf0204203

[233] Lanzotti $V$. The analysis of onion and garlic. $J$ Chromatography A 2006; 1112(1-2): 3-22. http://dx.doi.org/10.1016/j.chroma.2005.12.016

[234] Weiner L, Shin I, Shimon LJ, et al. Thiol-disulfide organization in alliin lyase (alliinase) from garlic (Allium sativum). Protein Sci 2009; 18(1): 196-205.

[235] Kubec R, Svobodovaand M, Velisek J. Distribution of Salk(en)ylcysteine sulfoxides in some Allium species. Identification of a new flavour precursor: S-Ethylcysteine sulfoxide (ethiin). J Agr Food Chem 2000; 48: 428-33. http://dx.doi.org/10.1021/jf990938f

[236] Kamel A, Saleh M. Recent studies on the chemistry and biological activities of the organosulfur compounds of garlic (Allium sativum). Stud Nat Products Chem 2000; 23: 455-85. http://dx.doi.org/10.1016/S1572-5995(00)80135-0 
[237] Amagase $\mathrm{H}$. Clarifying the real bioactive constituents of garlic. J Nutr 2006; 136(3): 716S-25S.

[238] Munchberg U, Anwar A, Mecklenburg S, Jacob C. Polysulfides as biologically active ingredients of garlic. Org Biomo Chem 2007; 5(10): 1505-18. http://dx.doi.org/10.1039/b703832a

[239] Yoo KS, Pike LM. Determination of flavor precursor compound S-alk(en)yl-L-cysteine sulfoxides by HPLC method and their distribution in Allium species. Scientia Hort 1998; 75: 1-10. http://dx.doi.org/10.1016/S0304-4238(98)00107-1

[240] Randle WM, Lancaster JE. Sulphur compounds in Alliums in relation to flavour quality. In: Brewster JL Ed. Onions and other vegetable alliums. CAB International, Wallingford, Oxfordshire, UK 2002; pp. 329-56.

[241] Brewster JL, Ed. Onions and other vegetable alliums. Crop Production Science in Horticulture $15.2^{\text {nd }}$ ed. CAB International, Wallingford, Oxfordshire, UK; 2008.

[242] Siegers C, Steffen B, Robkeand A, Pentz R. The effect of garlic preparations against tumor cell proliferation. Phytomedicine 1999; 6: 7-11. http://dx.doi.org/10.1016/S0944-7113(99)80028-2

[243] Harris JC, Cottrell SL, Plummer S, Lloyd D. Antimicrobial properties of Allium sativum (garlic). Appl Microb Biotech 2001; 57: 282-6.

http://dx.doi.org/10.1007/s002530100722

[244] Jackson R, McNeil B, Taylor C, Holl G, Ruf D, Gwebu ET. Effect of aged garlic extract in casepase-3 activity in vitro. Nutr Neurosci 2002; 5: 287-90.

http://dx.doi.org/10.1080/10284150290032012

[245] Davenport DM, Wargovich MJ. Modulation of cytochrome P450 enzymes by organosulfur compounds from garlic. Food Chem Toxicol 2005; 43(12): 1753-62. http://dx.doi.org/10.1016/j.fct.2005.05.018

[246] Wargovich MJ. Diallylsulfide and allylmethylsulfide are uniquely effective among organosulfur compounds in inhibiting CYP2E1 protein in animal models. J Nutr 2006; 136(3): 832S-4S.

[247] Knowles LM, Milner JA. Possible mechanisms by which allyl sulphides suppress neoplastic cell proliferation. J Nutr 2001; 131: 1061S-6S.

[248] Brady JF, Ishizaki H, Fukuto JM, et al. Inhibition of cytochrome P-450 2E1 by diallyl sulfide and its metabolites. Chem Res Toxicol 1991; 4: 642-7. http://dx.doi.org/10.1021/tx00024a008

[249] Kwak MK, Kim SG, Kwak JY, Novakand RF, Kim ND. Inhibition of cytochrome P450 2E1 expression by organosulfur compounds. Biochem Pharmacol 1994; 47: 531-9.

http://dx.doi.org/10.1016/0006-2952(94)90185-6

[250] Reicks MM, Crankshaw DL. Modulation of rat hepatic cytochrome P450 activity by garlic organosulfur compounds. Nutr Cancer 1996; 25: 241-8. http://dx.doi.org/10.1080/01635589609514448

[251] Sundaram SG, Milner JA. Impact of organosulfur compounds in garlic on canine mammary tumor cells in culture. Cancer Lett 1993; 74: 85-90. http://dx.doi.org/10.1016/0304-3835(93)90048-E

[252] Sakamoto K, Lawsonand LD, Milner JA. Allyl sulfides from garlic suppresses the in vitro proliferation of human A549 lung tumor cells. Nutr Cancer 1997; 29: 152-6. http://dx.doi.org/10.1080/01635589709514617

[253] Appel E, Rabinkov A, Neeman M, Kohen F, Mirelman D. Conjugates of daidzein-alliinase as a targeted pro-drug enzyme system against ovarian carcinoma. J Drug Targeting 2011; 19(5): 326-35

http://dx.doi.org/10.3109/1061186X.2010.504265
[254] Liu L, Yeh YY. Inhibition of cholesterol biosynthesis by organosulfur compounds derived from garlic. Lipids 2000; 35: 197-203. http://dx.doi.org/10.1007/BF02664770

[255] Ide N, Lau BH. Garlic compounds protect vascular endothelial cells from oxidized low-density lipoproteininduced injury. J Pharm Pharmacol 1997; 49: 908-11. http://dx.doi.org/10.1111/j.2042-7158.1997.tb06134.x

[256] Patrono C. Aspirin: new cardiovascular uses for an old drug. Am J Med 2001; 11: 62S-5S. http://dx.doi.org/10.1016/S0002-9343(00)00645-8

[257] Rahman K. Historical perspective on garlic and cardiovascular disease. J Nutr 2001; 131: 977S-9S.

[258] Lawson LD, Ransomand DK, Hughes BG. Inhibition of whole blood platelet aggregation by compounds in garlic clove extracts and commercial garlic preparations. Thromb Res 1992; 65: 141-56. http://dx.doi.org/10.1016/0049-3848(92)90234-2

[259] Morimitsu Y, Moriokaand Y, Kawakishi S. Inhibitors of platelet aggregation generated from mixtures of Allium species and/or S-alk(en)y-L-cysteine sulfoxides. J Agr Food Chem 1992; 40: 368-72.

http://dx.doi.org/10.1021/jf00015a002

[260] Ali M, Thomson M, Afzal M. Garlic and onions: their effect on eicosanoid metabolism and its clinical relevance. Prost Leuko Ess Fatty Acids 2000; 62: 55-73. http://dx.doi.org/10.1054/plef.1999.0124

[261] Hubbard GP, Wolffram S, Lovegrove JA, Gibbins JM. Ingestion of quercetin inhibits platelet aggregation and essential components of the collagen-stimulated platelet activation pathway in man: a pilot study. J Thromb Haem 2006; 2: 2138-45. http://dx.doi.org/10.1111/j.1538-7836.2004.01067.x

[262] Janssen K, Mensink RP, Cox FJ, et al. Effects of flavonoids quercetin and apigenin on hemostasis in healthy volunteers: results from an in vitro and a dietary supplement study. Am J Clin Nutr 1998; 67: 255-62.

[263] Osmont KS, Arnt CR, Goldman IL. Temporal aspects of onion-induced antiplatelet activity. Plant Food Hum Nutr 2003; 58: 27-40. http://dx.doi.org/10.1023/A:1024062330700

[264] Lau BH, Yamasakiand T, Gridley DS. Garlic compounds modulate macrophage and T-lymphocyte functions. Mol Biother 1991; 3: 103-7.

[265] Feng ZH, Zhangand GM, Hao TL. Effect of dially trisulfide on the activation of $\mathrm{T}$ cell and macrophage-mediated cytotoxicity. J Tongji Med Univ 1994; 14: 142-9. http://dx.doi.org/10.1007/BF02886794

[266] Amagase H, Petesch BL, Matsuura H, Kasuga S, Itakura $Y$. Intake of garlic and its bioactive components. J Nutr 2001; 131(3): 955S-62S.

[267] Goncagul G, Ayaz E. Antimicrobial effect of garlic (Allium sativum). Recent Patents on Anti-infective Drug Discov 2010; 5(1): 91-3.

\section{http://dx.doi.org/10.2174/157489110790112536}

[268] Sheela CG, Kumud K, Augusti KT. Anti-diabetic effect of onion and garlic sulfoxide amino acids in rats. Planta Med 1995; 61: 356-7. http://dx.doi.org/10.1055/s-2006-958099

[269] Augusti KT, Sheela CG. Antiperoxide effect of S-allyl cysteine sulfoxide, an insulin secretagogue, in diabetic rats Experientia 1996; 52: 115-20. http://dx.doi.org/10.1007/BF01923354

[270] Agarwal KC. Therapeutic actions of garlic constituents. Med Res Rev 1996; 16(1): 111-24. http://dx.doi.org/10.1002/(SICI)10981128(199601)16:1<111::AID-MED4>3.0.CO;2-5 
[271] Wagner H, Dorsch W, Bayer T, Breu W, Willer F. Antiasthmatic effects of onions: inhibition of 5-lipoxygenase and cyclooxygenase in vitro by thiosulfinates and "cepaenes". Prost Leuko Ess Faty Acids 1990; 39: 59-62. http://dx.doi.org/10.1016/0952-3278(90)90173-I

[272] Cao G, Muccitelli HU, Sanchez-Morenoand C, Prior R. Anthocyanins are absorbed in glyated forms in elderly women: a pharmacokinetic study. Am J Clin Nutr 2001; 73: 920-6.

[273] Delgado-Vargas F, Paredes-López O, Eds. Natural colorants for food and nutraceutical uses. CRC Press, Boca Raton. FL 2003.

[274] Horbowicz M, Kosson R, Grzesiuk A, Bski HD. Anthocyanins of fruits and vegetables - their occurrence analysis and role in human nutrition. Vegetable Crops Res Bull 2008; 68: 5-22. http://dx.doi.org/10.2478/v10032-008-0001-8

[275] Lila MA. Anthocyanins and human health: an in vitro investigative approach. J Biomed Biotechnol 2004; 5: 30613.

http://dx.doi.org/10.1155/S111072430440401X

[276] Rechner AR, Kroner C. Anthocyanins and colonic metabolites of dietary polyphenols inhibit platelet function. Thromb Res 2005; 116: 327-34. http://dx.doi.org/10.1016/j.thromres.2005.01.002

[277] Noda Y, Kaneyuki T, Igarashi K, Moriand A, Pacer L. Antioxidant activity of nasunin, an anthocyanin in eggplant. Res Commun Mol Path Pharmacol 1998; 102: 175-87.

[278] Kayamori F, Igarashi K. Effect of dietary nasunin on the serum cholesterol level in rats. Biosci Biotech Biochem 1994; 58: $570-1$. http://dx.doi.org/10.1271/bbb.58.570

[279] Hou DX. Potential mechanisms of cancer chemoprevention by anthocyanins. Curr Mol Med 2003; 3: 149-159. http://dx.doi.org/10.2174/1566524033361555

[280] Stintzing FC, Stintzing AS, Carle R, Frei B, Wrolstad RE. Color and antioxidant properties of cyanidin-based anthocyanin pigments. J Agric Food Chem 2002; 50: 617281.

http://dx.doi.org/10.1021/jf0204811

[281] Crozier A, Lean ME, McDonaldand MS, Black C. Quantitative analysis of the flavonoid content of commercial tomatoes, onions, lettuce and celery. J Agr Food Chem 1997; 45: 5905. http://dx.doi.org/10.1021/j960339y

[282] Crozier A, Burns J, Aziz AA, et al. Antioxidant flavonols from fruits, vegetables and beverages: measurements and bioavailability. Biol Res 2000; 33(2): 79-88. http://dx.doi.org/10.4067/S0716-97602000000200007

[283] Eloesser W, Herrmann K. Flavanols and flavones of vegetable. V. Flavanols and flavones of root vegetables. Z Lebensm Unters Forch 1975; 16: 265-70.

http://dx.doi.org/10.1007/BF01139578

[284] DuPont MS, Mondin Z, Williamson G, Price KR. Effect of variety, processing and storage on the flavonoid glycoside content and composition of lettuce and endive. J Agr Food Chem 2000; 48: 3957-64.

http://dx.doi.org/10.1021/jf0002387

[285] Miean KH, Mohamed S. Flavonoid (myricetin, quercetin, kaempferol, luteolinand apigenin) content of edible tropical plants. J Agr Food Chem 2001; 49: 106-12. http://dx.doi.org/10.1021/jf000892m

[286] Negre-Salvayre A, Salvayre R. Quercetin prevents the cytotoxicity of oxidised LDL on lymphoid cell lines. Free Radic Biol Med 1992; 12: 101-6. http://dx.doi.org/10.1016/0891-5849(92)90002-X

[287] Lio M, Kawaguchi H, Sakota Y, Otonari J, Nitahara H. Effects of polyphenols, including flavonoids, on glutathione
S-transferase and glutathione reductase. Biosci Biotech Biochem 1993; 57: 1678-80.

http://dx.doi.org/10.1271/bbb.57.1678

[288] Bohm H, Boeing H, Hempel J, Raab B, Kroke A. Flavonols, flavonesand anthocyanins as natural antioxidants of food and their possible role in the prevention of chronic diseases. $Z$ Ernahrungswiss 1998; 37: 147-63.

[289] Gryglewski RJ, Korbut R, Robak J. On the mechanism of antithrombotic action of flavonoids. J Biochem Pharmaco 1987; 36: 317-21. http://dx.doi.org/10.1016/0006-2952(87)90288-7

[290] Cook NC, Samman S. Flavonoids-chemistry, metabolism, cardioprotective effects and dietary sources. J Nutr Biochem 1996; 7: 66-76. http://dx.doi.org/10.1016/0955-2863(95)00168-9

[291] Baker ME, Medlock KL, Sheehan DM. Flavonoids inhibit estrogen binding to rat alpha-fetoprotein. Expt Boil Med 1998; 217: 317-21.

[292] Hou EX, Fukuda M, Johnson JA, Miyamori K, Ushikai M, Fujii $M$. Fisetin induces transcription of NADPH: quinine oxidoreductase gene through an antioxidant responsive element-involved activation. Int J Oncol 2001; 18: 1175-9.

[293] Vinson JA, Jang J, Dabbagh YA, Serry MM, Cai S. Plant polyphenols exhibit lipoprotein-bond antioxidant activity using an in vitro oxidation model for heart disease. J Agric Food Chem 1995; 43: 2798-9. http://dx.doi.org/10.1021/jf00059a004

[294] Paganga G, Millerand N, Rice-Evans CA. The polyphenolic content of fruit and vegetables and their antioxidant activities: What does a serving constitute?. Free Rad Res 1999; 30: 153-62. http://dx.doi.org/10.1080/10715769900300161

[295] Cermak R. Effect of dietary flavonoids on pathways involved in drug metabolism. Expert Opin Drug Metab Toxicol 2008; 4(1): 17-35

http://dx.doi.org/10.1517/17425255.4.1.17

[296] de Whalley CV, Rankin SM, Hoult JR, Hessupand W, Leake DS. Flavonoids inhibit the oxidative modification of lowdensity lipoproteins by macrophage. Biochem Pharmacol 1990; 39: 1743-50. http://dx.doi.org/10.1016/0006-2952(90)90120-A

[297] Ullmannova V, Popescu NC. Inhibition of cell proliferation, induction of apoptosis, reactivation of DLC1, and modulation of other gene expression by dietary flavone in breast cancer cell lines. Cancer Detect Prev 2007; 31(2): 110-8. http://dx.doi.org/10.1016/j.cdp.2007.02.005

[298] Hosny M, Rosazza JP. New isoflavone and triterpene glycosides from soybeans. J Nat Prod 2002; 65: 805-13. http://dx.doi.org/10.1021/np010606g

[299] Xu DP, Xiao K, Gu WY, Ding XL. Isolation of a new isoflavone from soybean germ. Zhongcaoyao 2003; 34: 1065-7.

[300] Halbrock K. Flavonoids. In: Conn EE, Ed. Biochemistry of Plant. Academic Press, New York 1981; pp. 425-6.

[301] Liggins J, Bluck JC, Runswick S, Atkinson C, Cowardand WA, Bingham SA. Daidzein and genistein contents of vegetables. Br J Nutr 2000; 84: 717-25.

[302] Vacek J, Klejdus B, Lojkova L, Kuban V. Current trends in isolation, separation, determination and identification of isoflavones: a review. J Sep Sci 2008; 31: 2054-67. http://dx.doi.org/10.1002/jssc.200700569

[303] Dentith S, Lockwood B. Development of techniques for the analysis of isoflavones in soy foods and nutraceuticals. Curr Opin Clin Nutr Metab Care 2008; 11: 242-7.

http://dx.doi.org/10.1097/MCO.0b013e3282fa15c9

[304] Yu O, Jung W, Shi J, et al. Production of the isoflavones genistein and daidzein in non-legume dicot and monocot tissues. Plant Physiol 2000; 124: 781-94.

http://dx.doi.org/10.1104/pp.124.2.781 
[305] Goldwyn S, Lazinskyand A, Wei H. Promotion of health by soy isoflavones: efficacy, benefit and safety concerns. Drug Metabol Drug Interact 2000; 7: 261-89.

[306] Ren MQ, Kuhn G, Wegner J, Chen J. Isoflavones, substances with multi-biological and clinical properties. Eur $\mathrm{J}$ Nutr 2001; 40: 135-46. http://dx.doi.org/10.1007/PL00007388

[307] Messina M, Kucuk O, Lampe JW. An overview of the health effects of isoflavones with an emphasis on prostate cancer risk and prostate-specific antigen levels. J AOAC Int 2006; 89: 1121-34.

[308] Larkin T, Price WE, Astheimer L. The key importance of soy isoflavone bioavailability to understanding health benefits. Crit Rev Food Sci Nutr 2008; 48: 538-52. http://dx.doi.org/10.1080/10408390701542716

[309] Wiseman $\mathrm{H}$. The bioavailability of non-nutrient plant factors: dietary flavonoids and photo-estrogens. Proc Nutr Soc 1999; 58: 139-46. http://dx.doi.org/10.1079/PNS19990019

[310] Sarkar FH, Li Y. Isoflavones, soybean phytoestrogens, and cancer. In: Awad AB, Bradford PG, Eds. Nutrition and Cancer Prevention. CRC Press, Boca Raton, FL 2006; pp. 295-312.

[311] Clarkson TB. Soy, soy phytoestrogens and cardiovascular disease. J Nutr 2002; 132: 566S-9S.

[312] Brynin R. Soy and its isoflavones: a review of their effects on bone density. Altern Med Rev 2002; 7: 317-27.

[313] Messina M, Ho S, Alekel DL. Skeletal benefits of soy isoflavones: a review of the clinical trial and epidemiologic data. Curr Opin Clin Nutr Metab Care 2004; 7: 649-58. http://dx.doi.org/10.1097/00075197-200411000-00010

[314] Orgaard A, Jensen L. The effects of soy isoflavones on obesity. Exp Biol Med 2008; 233: 1066-80. http://dx.doi.org/10.3181/0712-MR-347

[315] Barnes S, Boersma B, Patel R, et al. Isoflavonoids and chronic disease: mechanisms of action. Biofactors 2000; 12: 209-15.

http://dx.doi.org/10.1002/biof.5520120133

[316] Messina M. A brief historical overview of the past two decades of soy and isoflavone research. J Nutr 2010; 140: $1350 \mathrm{~S}-4 \mathrm{~S}$.

http://dx.doi.org/10.3945/jn.109.118315

[317] Barnes S. The biochemistry, chemistry and physiology of the isoflavones in soybeans and their food products. Lymphat Res Biol 2010; 8: 89-98. http://dx.doi.org/10.1089//rb.2009.0030

[318] Lee HP, Gourley L, Duffy SW, Esteve J, Leeand J, Day NE. Dietary effects on breast cancer risk in Singapore. Lancet 1991; 33: 1197-200. http://dx.doi.org/10.1016/0140-6736(91)92867-2

[319] Ziegler RG, Hooverand RN, Hildeshein RN. Migration patterns and breast cancer risk in Asian-America women. J Nat Cancer Inst 1993; 85: 1819-27. http://dx.doi.org/10.1093/jnci/85.22.1819

[320] Lamartiniere C. Protection against breast cancer with genistein: a component of soy. Am J Clin Nutr 2000; 71: 1705S-7S.

[321] Steiner C, Arnould S, Scalbert A, Manach C. Isoflavones and the prevention of breast and prostate cancer: new perspectives opened by nutrigenomics. Br J Nutr 2008; 99(1): 78-108. http://dx.doi.org/10.1017/S0007114508965788

[322] Messina MJ, Wood CE. Soy isoflavones, estrogen therapy, and breast cancer risk: analysis and commentary. Nutr $\mathrm{J}$ 2008; 7: 17. http://dx.doi.org/10.1186/1475-2891-7-17

[323] Dong JY, Qin LQ. Soy isoflavones consumption and risk of breast cancer incidence or recurrence: a meta-analysis of prospective studies. Breast Cancer Res Treat 2011; 125: 315-23.

http://dx.doi.org/10.1007/s10549-010-1270-8

[324] Jiang HY, Lv FJ, Tai JQ. Bioactive components of soybean and their function. Soybean Sci 2000; 19: 160-4.

[325] Sarkar FH, Li Y. Soy isoflavones and cancer prevention. Cancer Invest 2003; 21: 744-57. http://dx.doi.org/10.1081/CNV-120023773

[326] Verhoeven DTH, Goldbohm RA, van Poppel G, Verhagen H, van den Brandt PA. Epidemiological studies on Brassica vegetables and cancer risk. Cancer Epidem Biomarkers Prev 1996; 5: 733-51.

[327] Ambrosone CB, McCann SE, Freudenheim JL, Marshall JR, Zhang Y, Shields PG. Breast cancer risk in premenopausal women is inversely associated with consumption of broccoli, a source of isothiocyanates, but is not modified by GST genotype. J Nutr 2004; 134: 1134-8.

[328] Brennan P, Hsu CC, Moullan N, et al. Effect of cruciferous vegetables on lung cancer in patients stratified by genetic status: a mendelian randomisation approach. Lancet 2005 366: 1558-60.

http://dx.doi.org/10.1016/S0140-6736(05)67628-3

[329] Kirsh VA, Peters U, Mayne ST, et al. Prospective study of fruit and vegetable intake and risk of prostate cancer. J Natl Cancer Inst 2007; 99: 1200-9.

http://dx.doi.org/10.1093/jnci/djm065

[330] Traka M. Broccoli consumption interferes with prostate cancer progression: mechanisms of action. Acta Hort 2010; 867: 19-25.

[331] Kohlmeier L, Su L. Cruciferous vegetables consumption and colorectal cancer risk: meta-analysis of the epidemiological evidence. FSEB J 1997; 11: 369.

[332] Seow A, Yuan JM, Sun CL, Van Den Berg D, Lee HP, Yu MC. Dietary isothiocyanates, glutathione S-transferase polymorphisms and colorectal cancer risk in the Singapore Chinese Health Study. Carcinogenesis 2002; 23: 2055-61. http://dx.doi.org/10.1093/carcin/23.12.2055

[333] VanEtten $\mathrm{CH}$, Dzenbichler ME, Williams $\mathrm{P}$, Kwolek WF Glucosinolates and derived products in cruciferous vegetables. Analysis in the edible part from twenty-two varieties of cabbage. J Agr Food Chem 1976; 24: 452-5. http://dx.doi.org/10.1021/jf60205a049

[334] Carlson DG, Daxenbichler ME, Van Etten CH, Tookey HL, Williams PH. Glucosinolates in crucifer vegetables: turnip and rutabagas. J Agr Food Chem 1981; 29: 1235-9. http://dx.doi.org/10.1021/jf00108a034

[335] Carlson DG, Daxenbichler ME, VanEtten CH, Hill CB, Williams PH. Glucosinolates in radish cultivars. J Am Soc Hort Sci 1985; 110: 634-8.

[336] Carlson DG, Daxenbichler ME, VanEtten CH, Kwolek WF Williams PH. Glucosinolates in crucifer vegetables: broccoli, Brussels sprouts, cauliflower, collards, kale, mustard green, and kohlrabi . J Am Soc Hort Sci 1987a; 112: 173-8.

[337] Carlson DG, Daxenbichler ME, VanEtten $\mathrm{CH}$, Kwolek WF, Hill CB, Williams PH. Glucosinolates in turnip tops and roots: cultivars grown for greens and/or roots. J Am Soc Hort Sci 1987b; 112: 179-83.

[338] Kushad MK, Brown AF, Kurillicn AC, et al. Variation in glucosinolates in vegetable crops of Brassica oleracea. $J$ Agric Food Chem 1999; 47: 1541-8. http://dx.doi.org/10.1021/jf980985s

[339] Ciska E, Martyniak-Przybyszewska B, Kozlowska H. Content of glucosinolates in cruciferous vegetables grown at the same site for two years under different climatic condition. $J$ Agr Food Chem 2000; 48: 2862-7. http://dx.doi.org/10.1021/jf981373a 
[340] Vallejo F, Tomas-Barberan FA, Garcia-Viguera C. Potential bioactive compounds in health promotion from broccoli cultivars grown in Spain. J Sci Food Agric 2002; 82: 1293-7. http://dx.doi.org/10.1002/jsfa.1183

[341] Vallejo F, Tomas-Barberan FA, Banavent-Garcia AG, GarciaViguera $C$. Total and individual glucosinolate contents in inflorescences of eight broccoli cultivars grown under various climatic and fertilization conditions. J Sci Food Agric 2003; 83: 307-13.

http://dx.doi.org/10.1002/jsfa.1320

[342] Nilsson $\mathrm{J}$, Olsson $\mathrm{K}$, Engqvist $\mathrm{G}$, et al. Variation in the content of glucosinolates, hydroxycinnamic acids, carotenoids, total antioxidant capacity and low-molecularweight carbohydrates in Brassica vegetables. J Sci Food Agric 2006; 86: 528-38.

http://dx.doi.org/10.1002/jsfa.2355

[343] Borkowski J, Szajdek A, Borkowska EJ, Ciska E, Zielinski H. Content of selected bioactive components and anti oxidant properties of broccoli (Brassica oleracea L.). Eur Food Res Tech 2008; 226: 459-65.

http://dx.doi.org/10.1007/s00217-006-0557-9

[344] Cartea ME, Velasco P, Obregón S, Padilla G, de Haro A. Seasonal variation in glucosinolate content in Brassica oleracea crops grown in northwestern Spain. Phytochemistry 2008; 69: 403-10.

http://dx.doi.org/10.1016/i.phytochem.2007.08.014

[345] Kusznierewics B, Bartoszek A, Wolska L, Drzewiwcki J, Gorinstein S, Namiesnik J. Partial characterization of white cabbages (Brassica oleracea var. capitata f. alba) from different regions by glucosinolates, bioactive compounds, total antioxidant activities and proteins. LWT 2008; 41: 1-9. http://dx.doi.org/10.1016/j.Iwt.2007.02.007

[346] Cao G, Sofic E, Prior RL. Antioxidant capacity of tea and common vegetables. J Agr Food Chem 1996; 44: 3426-31. http://dx.doi.org/10.1021/jf9602535

[347] Kurilich A, Tsau GJ, Brown A, et al. Carotene, tocopherol and ascorbate contents in sub-species of Brassica oleracea. J Agr Food Chem 1999; 47: 1576-81. http://dx.doi.org/10.1021/j9810158

[348] Konings EJM, Roomans HH, Dorant E, Goldbohm RA, Saris $\mathrm{WH}$, van den Brandt PA. Folate intake of the Dutch population according to newly established liquid chromatography data for foods. Am J Clin Nutr 2001; 73(4): 765-76.

[349] Fermenia A, Selvendran RR, Ring SG, Robertson JA. Effects of heat treatment and dehydration on properties of cauliflower fiber. J Agr Food Chem 1999; 47: 728-32. http://dx.doi.org/10.1021/j9980462k

[350] Rahn CR, Bending GD, Lillywhite RD, Turner MK. Chemical characterisation of vegetable and arable crops residue materials: a comparison of methods. J Sci Food Agr 1999; 79: 1715-21. http://dx.doi.org/10.1002/(SICI)10970010(199909)79:12<1715::AID-JSFA426>3.0.CO;2-V

[351] Kubec R, Svobodova M, Velisek J. Gas-chromatographic determination of S-alk(eny)lylcysteine sulfoxide. J Chromatogr 1999; 862: 85-94.

http://dx.doi.org/10.1016/S0021-9673(99)00902-4

[352] Hertog MG, Hollman PC, Katan MB. Content of potentially anticarcinogenic flavonoids of 28 vegetables and fruits commonly consumed in The Netherlands. J Agr Food Chem 1992; 40: 2379-83.

http://dx.doi.org/10.1021/jf00024a011

[353] Herrmann K. Flavonols and flavones in food plants: a review. J Food Technol 1976; 11: 433-48. http://dx.doi.org/10.1111/j.1365-2621.1976.tb00743.x

[354] Bilyk A, Sapers GM. Distribution of quercetin and kaemperol in lettuce, kale, chive, garlic chive leek, horseradish, red radish and red cabbage tissue. J Agr Food Chem 1985; 33: 226-8.

http://dx.doi.org/10.1021/jf00062a017

[355] Ip C, Lisk DJ. Enrichment of selenium in allium vegetables for cancer prevention. Carcinogenesis 1994; 15: 1881-5.

http://dx.doi.org/10.1093/carcin/15.9.1881

[356] Wang $\mathrm{H}$, Kruszewki A, Brautigan DL. Cellular chromium activation of insulin receptor kinase. Biochemistry 2005; 44: 8167-75.

http://dx.doi.org/10.1021/bi0473152

[357] Ritsema T, Smeekens S. Fructans: beneficial for plants and humans. Curr Opin Plant Biol 2003; 6: 223-30. http://dx.doi.org/10.1016/S1369-5266(03)00034-7

[358] Kruse HP, Kleessen B, Blaut M. Effects of inulin on faecal bifidobacteria in human subjects. Br J Nutr 1999; 82: 375-82.

[359] Kilian S, Kritzinger S, Rycroft C, Gibson GR, du Preez J. The effects of the novel bifidogenic trisaccharide, neokestose, on the human colonic microbiota. World J Microb Biotech 2002; 18: $637-44$ http://dx.doi.org/10.1023/A:1016808015630

[360] Scholz-Ahrens KE, Schaafsma G, van den Heuvel EGHM, Schrezenmeir J. Effects of prebiotics on mineral metabolism. Am J Clin Nutr 2001; 73: 459S-64S.

[361] Jackson KG, Taylor GR, Clohessy AM, Willieams CM. The effect of the daily intake of inulin on fasting lipid, insulin and glucose concentrations in middle-aged men and women. $\mathrm{Br} \mathrm{J}$ Nutr 1999; 82: 23-30.

[362] Srinivasan K. Plant foods in the management of diabetes mellitus: Spices as beneficial antidiabetic food adjuncts. Int $\mathrm{J}$ Food Sci Nutr 2005; 56: 399-414. http://dx.doi.org/10.1080/09637480500512872

[363] Clinton S. Lycopene: Chemistry, biology and implication for human health and disease. Nutr Rev 1998; 56: 35-51. http://dx.doi.org/10.1111/j.1753-4887.1998.tb01691.x

[364] Scott KJ, Hart DJ. Development and evolution of an HPLC method for the analysis of carotenoids food and the measurement of the carotenoid content vegetables and fruits commonly consumed in the UK. Food Chem 1995; 54: 10111.

http://dx.doi.org/10.1016/0308-8146(95)92669-B

[365] Tonucci LH, Holden JM, Beecher GR, Khachik F, Davis CS, Mulokozi G. Carotenoid content of thermally processed tomato-based food products. J Agri Food Chem 1995; 43: 579-86. http://dx.doi.org/10.1021/jf00051a005

[366] Gerster $\mathrm{H}$. The potential role of lycopene for human health. J Am Coll Nutr 1997; 16: 109-26.

[367] Albushita AA, Daood HG, Biacs PA. Change in carotenoids and antioxidant vitamins in tomato as a function of varietal and technological factors. J Agr Food Chem 2000; 48: 207581. http://dx.doi.org/10.1021/jf990715p

[368] Leonardi C, Ambrosino P, Esposito F, Fogliano V. Antioxidant activity and caroteoid and tomatine contentes in different typologies of fresh consumption tomatoes. J Agr Food Chem 2000; 48: 4723-7. http://dx.doi.org/10.1021/jf000225t

[369] Arab L, Steck S. Lycopene and cardiovascular disease. Am J Clin Nutr 2000; 71: 1691S-5S.

[370] Giovannucci E. Tomatoes, tomato based products, lycopene and cancer: review of the epidemiological literature. J Natl Cancer Institute 1999; 91: 317-31.

http://dx.doi.org/10.1093/jnci/91.4.317

[371] Dietary Guidelines Advisory Committee. Report of the Dietary Guidelines Advisory Committee. Washington, DC; 2005. Available from: http: //www.health.gov/dietaryguidelines/dga2005/report/HTML/C_ Methodology.htm. 
[372] Rao AV, Rao LG. Carotenoids and human health. Pharmacol Res 2007; 55(3): 207-16. http://dx.doi.org/10.1016/j.phrs.2007.01.012

[373] Albushita AA, Hebshi EA, Daood HG, Biacs PA. Determination of antioxidant vitamins in tomato. Food Chem 1997; 60: 207-12. http://dx.doi.org/10.1016/S0308-8146(96)00321-4

[374] Stewart AJ, Bozonnet S, Mullen W, Jenkins Gl, Lean ME, Crozier A. Occurrence of flavonols in tomatoes and tomatobased products. J Agr Food Chem 2000; 48: 2663-9. http://dx.doi.org/10.1021/jf000070p

[375] McCay CM, McCay JB, Smith O. The nutritive value of potato. In: Talburt WF, Smith O, Eds. Potato processing. AVI, Westport, CT 1987; pp. 287-331.

[376] Okeyo J, Kushad M. Composition of four potato cultivars in relation to cold storage and reconditioning. Hort Technol 1995; 5: 250-3.

[377] Friedman $M$. The nutritional value of proteins from different food sources: a review. J Agr Food Chem 1996; 44: 6-29. http://dx.doi.org/10.1021/jf9400167

[378] Friedman M. Chemistry, biochemistry and dietary role of potato polyphenols: a review. J Agr Food Chem 1997; 45: 1523-40. http://dx.doi.org/10.1021/jf960900s

[379] Jung CS, Griffiths HM, De Jong DM, Cheng S, Bodis M, De Jong WS. The potato $P$ locus codes for flavonoid 3',5'hydroxylase. Theor Apl Genet 2005; 110(2): 269-75. http://dx.doi.org/10.1007/s00122-004-1829-z

[380] Reeve RM, Hautala E, Weaver ML. Anatomy and compositional variation within potatoes II. Phenolics, enzymes and other minor components. Am Potato J 1969; 46: 374-86

http://dx.doi.org/10.1007/BF02869558

[381] Thomas $P$, Joshi MR. Prevention of after-cooking darkening of irradiated potatoes. Potato Res 1977; 20: 77-84. http://dx.doi.org/10.1007/BF02362302

[382] Al-Saikhan MS, Howard LR, Miller JC. Antioxidant activity and total phenolics in different genotypes of potato (Solanum tuberosum L.). J Food Sci 1995; 60: 341-4.

http://dx.doi.org/10.1111/j.1365-2621.1995.tb05668.x

[383] Hasegawa D, Johnson RM, Gould WA. Effect of cold storage on chlorogenic acid content of potatoes. J Agr Food Chem 1966; 14: 165-9.

http://dx.doi.org/10.1021/jf60144a020

[384] Cieslik E. The effect of naturally occurring vitamin C in potato tubers on the levels of nitrates and nitriles. Food Chem 1994; 49: 233-5.

http://dx.doi.org/10.1016/0308-8146(94)90165-1

[385] Hagg M, Hakkinen R, Kumpulainen J, Ahvenainen R, Hurme E. Effect of preparation procedures, packaging and storage on nutrient retention of peeled potato. J Sci Food Agr 1998; 77: $519-26$

http://dx.doi.org/10.1002/(SICI)10970010(199808)77:4<519::AID-JSFA75>3.0.CO:2-C

[386] Ong AS, Tee ES. Natural sources of carotenoids from plants and oils. Meth Enzymol 1992; 213: 142-67.

http://dx.doi.org/10.1016/0076-6879(92)13118-H

[387] Packer L. Vitamin E is natures' master antioxidant. Sci Med 1994; 11: 54-63.

[388] Lachman J, Hamouz JK, Orsak M, Pivec V. Potato tubers as a significant source of antioxidants in human nutrition. Rostl Vyroba 2000; 46: 231-6.

[389] Djujic I, Djujic B, Trajkovic L. Dietary intake of selenium in Serbia: results for 1991. Conf Selenium Nauc Skup Srp Akad Nauk Umet 1995; 6: 81-7.

[390] Bosland PW. Capsicums: Innovative uses of an ancient crop. In: Janick J, Ed. Progress in new crops. ASHS Press, Arlington, VA 1996; pp. 479-87.
[391] Howard LR, Talcott ST, Brenes CH, Villalon B. Changes in phytochemical and antioxidant activity of selected pepper cultivars (Capsicum species) as influenced by maturity. J Agr Food Chem 2000; 48: 1713-20.

http://dx.doi.org/10.1021/jf990916t

[392] Howard LR, Smith RT, Wagner AB, Villalon B, Burns EE. Provitamin $A$ and ascorbic acid content of fresh pepper cultivars (Capsicum annum) and processed jalapenos. J Food Sci 1994; 59: 362-5.

http://dx.doi.org/10.1111/j.1365-2621.1994.tb06967.x

[393] Lee Y, Howard R, Villalon B. Flavonoids and antioxidant activity of fresh pepper (Capsicum annum) cultivars. J Food Sci 1995; 60: 473-6.

http://dx.doi.org/10.1111/j.1365-2621.1995.tb09806.x

[394] Szallasi A, Blumberg PM. Vanilloid (capsaicin) receptors and mechanisms. Pharmacol Rev 1999; 51: 159-11.

[395] Noda Y, Kneyuki T, Igarashi K. Antioxidant activity of nasunin, an anthocyanin in eggplant peels. Toxicology 2000; 148(2-3): 119-23.

http://dx.doi.org/10.1016/S0300-483X(00)00202-X

[396] Matsuzoe N, Yamaguchi M, Kawanobu S, Watanabe $Y$, Higashi $H$, Sakata $Y$. Effect of dark treatment of the eggplant on fruit skin color and its anthocyanin components. J Japan Soc Hort Sci 1999; 68: 138-45.

http://dx.doi.org/10.2503/jishs.68.138

[397] Ben-Amos A, Fishler R. Analysis of carotenoids with emphasis on 9 -cis $\beta$-carotene in vegetables and fruits commonly consumed in Israel. Food Chem 1998; 62: 515-20. http://dx.doi.org/10.1016/S0308-8146(97)00196-9

[398] Ensminger AH, Esminger ME, Kondale JE, Robson JRK Food for Health: A Nutrition Encyclopedia. Pegus Press, Clovis, California 1986.

[399] Wood R. The Whole Foods Encyclopedia. Prentice-Hall Press; New York, NY 1988.

[400] Dhillon NPS, Monforte AJ, Pitrat M, et al. Melon landraces od India: contributions and importance. Plant Breed Rev 2012; 35: 85-150.

[401] Burger $Y$, Yeselson $Y$, Saar $U$, et al. Screening of melon (Cucumis melo) germplasm for consistently high sucrose content and for high ascorbic acid content. In: Lebeda A, Paris HS, Eds. Progress in Cucurbit genetics and breeding research. Proc. Cucurbitaceae 2004. Palacky University, Olomouc, Czech Republic 2004; pp.151-5.

[402] Crosby KM, Lester GE, Leskovar DI. Genetic variation for beneficial phytochemical levels in melons (Cucumis melo). In: Holmes GJ, Ed. Cucurbitaceae 2006. Universal Press, Raleigh, NC 2006; pp. 70-6.

[403] Mallillin AC, Trinidad TP, Raterta R, Dagbay K, Loyola AS. Dietary fibre and fermentability characteristics of root crops and legumes. Br J Nutr 2008; 100(3): 485-8. http://dx.doi.org/10.1017/S000711450891151X

[404] Trinidad TP, Mallillin AC, Loyola AS, Sagum RS, Encabo RR The potential health benefits of legumes as a good source of dietary fibre. Br J Nutr 2010; 103(4): 569-74.

http://dx.doi.org/10.1017/S0007114509992157

[405] Dias JS. World importance, marketing and trading of vegetables. Acta Horticulturae 2011; 921: 153-69.

[406] Almeida D. Manual de Culturas Hortícolas. Editorial Presença, Lisboa 2006; Vol. 1.

[407] Nielsen SE, Young JF, Daneshvar B, et al. Effect of parsley (Petroselinum crispum) intake on urinary apigenin excretion, blood antioxidant enzymes and biomarkers for oxidative stress in human subjects. Br J Nutr 1999; 81: 447-55.

[408] Ching LS, Mohamed S. Alpha-tocopherol content of 62 edible tropical plants. J Agr Food Chem 2001; 49: 3101-5. http://dx.doi.org/10.1021/jf000891u

[409] Simon PW, Goldman IL. Carrot. In: Sing RJ, Ed. Genetic Resources, Chromosome Engineering, and Crop 
Improvement. CRC Press, Boca Raton, FL, USA 2007; pp. 497-516.

[410] He T, Huang CY, Chen H, Hou YH. Effects of spinach powder fat-soluble extract on proliferation of human gastric adenocarcinoma cell. Biomed Environ Sci 1999; 12: 247-52.

[411] Prakash D, Nath $P, P a l$ M. Composition, variation of nutritional contents in leaves, seed protein, fat and fatty acid profile of chenopodium species. J Sci Food Agric 1993; 62(2): 203-5.

http://dx.doi.org/10.1002/jsfa.2740620214

[412] Sienera R. Oxalate contents of species of the Polygonaceae, Amaranthaceae and Chenopodiaceae families. Food Chem 2006; 98(2): 220-4.

http://dx.doi.org/10.1016/j.foodchem.2005.05.059 